\title{
Studies on the Urinary Steroids Metabolism of the Renal-Disease.
}

By

\section{Kazunari OKITSU}

The Third Department of Internal Medicine, Nagoya, University School of Medicine.

(Director : Prof. Dr. Kozo Yamada)

I inspected the Adrens Cortical Function and the sexal gland Function of the Renal Diseases. First practiced the fraction measurment of the $17 \mathrm{KS}$ in urine by the Chromatography. Second measured the Estrone Estradiol fraction by the Fluorometry as estrogen in urine. In addittion inspected variation of 17KS-fraction of the Nephrose Syndrome who was medicated several Hormones.

Details of this inspectations.

1) Measurment of urinary $17 \mathrm{KS}$ fraction was practiced by microscale elution chromatography. Its clinical usefullnes was corfirmed through the examination of Hydrolysis method, solvent density and eluate by standard substance.

2) There was no difference between the sexal gland fraction (IV V fraction) and the adrens fraction (VI VII fraction) on $17 \mathrm{KS}$ fraction measurment of healthy.

3) There are no remarkable change on the Akute Rinal Diseases but on the Chronic Rinal disease many of them there are remarkable decrease of VI VII fraction or IV V fraction. On Nephrose Syndrome IV V and VI VII fraction are remarkably decreased.

4) In course and variation of the Nephrose Syndrome and the $17 \mathrm{KS}$ fraction, III, IVV, VI VII fraction are increased with decreased of dropsy weight of body, decrease urine albumin and bloodplasma albumin figures improvement.

5) There is increase of VI VII fraction by medicate ACTH to the Nephrose Syndrome.

6) The Nephrose Syndrome (who are administrated with testosterone) metabolized a testosterone only about $1 / 2$ compare to healthy persons.

7) At the measurment of the Estone estradiol fraction in urine certified two peak in two healthy womens who was in praemenstral and ovulation but on the Nephrose Syndrome women there was no peak.

8) The Nephrose Syndrome who had clinical effects increased VI VII fraction but no clinicaly effected decreased III, IV V, VI VII fraction.

9) To Nephrose Syndrome medicate the Testosterone contonuously increased IV V fraction but more long time medicate Testosterone decreased VI VII fraction.

As above mentioned on Renal Diseases especialy on the Nephrose Syndrome is observed decline of function of glucocorticoid and the adrens corticale androgen and observed abstruction of metobolism. Beside on the Sexal gland there are declin of funetion of androgen and Estrogen but the Sexal gland second in its importance. 


\section{「腎疾患者におけるステロイド代謝の研究」}

\section{特に17KS 分劃について}

名古屋大学医学部山田内科教室 (主任 山田弘三教授)

研究生興津一成

（本論文の要旨は昭和 31 年 4 月 2 日第 29 回日本内分泌学会総会及び昭和 32 年 3 月 31 日第 30 回日本内 分泌学会総会に扔いて発表した）

\section{目次}

第 1 章 緒 論

第 2 章 実軻対照並びに実験方法

第 1 節 実験対照

第 2 節 実験方法

第 3 章 尿中 $17 \mathrm{KS}$ 分劃について

第 1 節 序 言

第 2 節 実験成績

第 1 項 健 康人

第 2 項 腎疾患者

第 3 項 高血圧病及び内分泌疾患者

第 4 項 ネフローゼ症候群㭧者の経過と $17 \mathrm{KS}$ 分劃

第 5 項 ACTH投与実験

第 6 項 テストステロン代謝率

第 3 節 小 括

第 4 章 尿中エストロゲンについて

第 1 節 序 言
第 2 節 実験成績

第 1 項 健 康人

第 2 項 ネフローゼ症候群患者

第 3 節 小 括

第 5 章 種々ホルモン負荷に於けるネフロー ゼ症候群患者尿中 $17 \mathrm{KS}$ 分劃の変動

第 1 節 序 言

第 2 節 実験成績

第 1 項 プレドニゾン

第 2 項 テストステロン

第 3 項 メチールアンドロスタンジオ一 ル

第 4 項 エストラジオール

第 3 節 小 括

第 6 章 総括及び考按

第 7 章 結 論

\section{第 1 章 緒}

\section{論}

近時内分泌学の研究が渚しく活潑となり, 䤏素化学, ビタミン学の急速な進展と相応じて飛躍的な発展を 続けている. ステロイドホルモンに関しては1927年 Butenandt, Doisy 等の estrone 純粋単離にはじまつて種 々の代謝産物の化学構造が明らかにされ, Lieberman \& Dobriner ${ }^{23)}$ 等は最近人尿中 42 種のケトステロイドの 化学的性質や前駆物筫と尿中代謝産物の関係を述べた。乙れによるとてれらステロイドの半数以上が副掔皮 質及び性腺系に由来すると考えられている，しかしててれ等の副腎皮質ホルモン，性ホルモンが水，電解貿， 糖，蛋白，脂肪等諸物望代謝に大きく関与している事は多くの学者が認めているとてろである，一方腎疾患 者殊に代謝病とまで考えられているネフローゼ症候群患者に於いて，下垂体副腎皮質及び性腺内分泌系が関

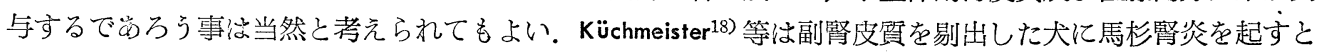
ネフローゼ症候群が起るととをたしかめ，Korenchevsky 19) 等虻性腺摘出ネズミの腎重量を測定すると，雄で

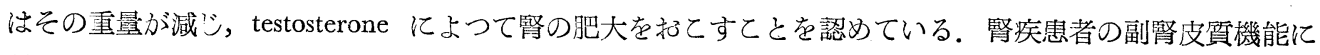
関しては，Thorn ${ }^{34)}$ 等は亜急性筒炎患者，ネフローゼ症候群患者に於ける尿中17KSは低值は示し，Farnsworth 
${ }^{11}$ (，三谷 ${ }^{39)}$ はネフローゼ症候群患者に於ける $17 \mathrm{KS}$ 排浛㽬は浮腫の認められた症例でば低值を，浮腫のない

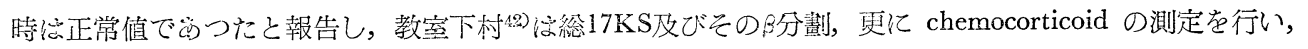

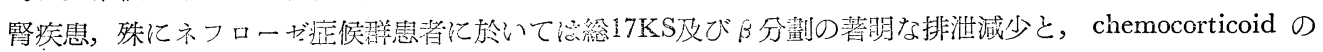
不定な異常排浛を諗め，アンドロゲン系ステロイドの減少するととを推論した，更にネフローゼ症候群に関

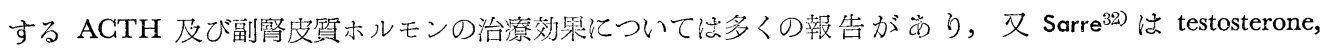
estradiol を投与して夹硢的馬杉筒炎ネフローゼの病像を阻止すると報告している.

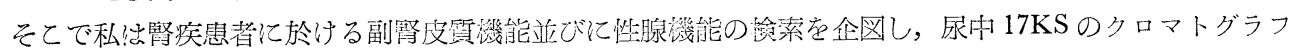
イーによる分劃測定を行い，副篮皮質本来の dehydroisoandrosterone 及び glucocorticoid より由来すると 考えられる 11 hydroxylated 17KS と, androgen 由来つ androsterone, etiocholanolone を分離定量した。

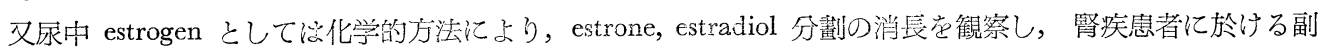

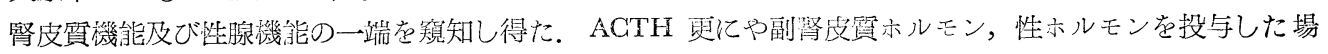

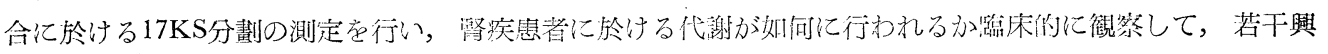

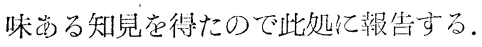

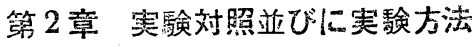

\section{第直節 寒 験 対 照}

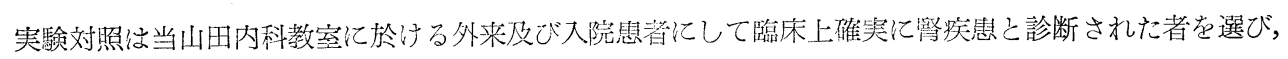

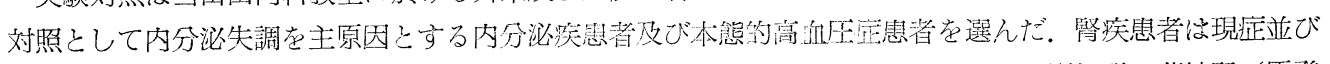

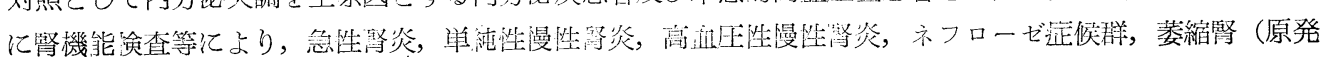
性及び続発性萎縮腎) に分類した。

第 2 籓 实 験 方 法

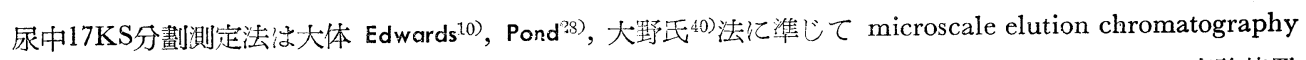
を実施し，総17KSとしては三宅氏11变法に従い別の操作により測定した. クロマトグラフイーの実験装置 については，従来の方法は水流 ポンプによる陰圧法, 二連球に よる加圧法等であるが，私に゙図 1 の如く水玨により平王にもど すととなく一定加圧状態に於い て, 溶秋を自由に添加出来乃椂 に簡易加圧溶出クロマトグラフ 装犆を考按した，此れにより溶 出時間は短縮されて約 4 時間で 終る事力出来る。 column は総 ガラス性で内烽 $4 \mathrm{~mm}$ 高さ $20 \mathrm{~cm}$ とし, 圧は $40 \mathrm{~mm} \sim 45 \mathrm{~mm} \mathrm{Hg} の$ 陽圧を加えた，加水分解につい ては表 1 の如く，標準物躓とし て帝国蔵器社製の dehydroisoandrosterone 及び androsterone を1000 r使用し，各種塩酸濃度， 加熱時閶, 加熱温度に於ける回 收率をみたとてろ，20\%，80\%，

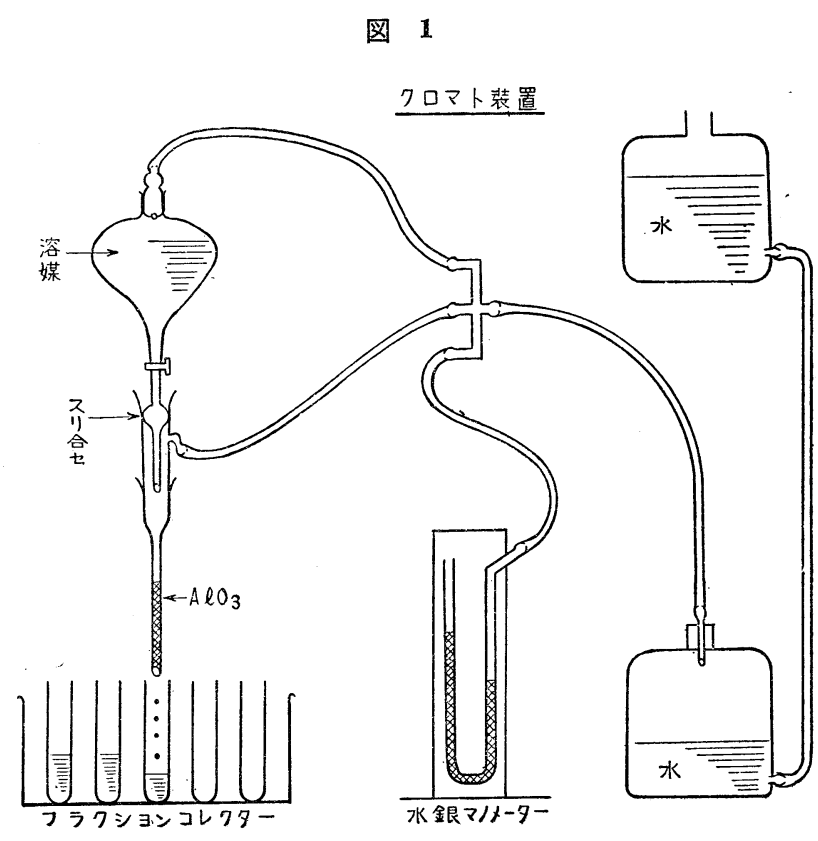


表 1 加水分解之回收率

\begin{tabular}{|c|c|c|c|c|c|}
\hline \multicolumn{3}{|c|}{ DEHYDROISOANDROSTERONE } & \multicolumn{3}{|c|}{ ANDROSTERONE } \\
\hline $\begin{array}{l}80^{\circ} \mathrm{G} \\
\mathrm{HcL}\end{array}$ & $\begin{array}{l}30 \text { 分 } \\
20 \%\end{array}$ & $864 \gamma$ & $\begin{array}{l}80^{\circ} \mathrm{C} \\
\mathrm{HcL}\end{array}$ & $\begin{array}{l}30 \text { 分 } \\
20 \%\end{array}$ & $645 \gamma$ \\
\hline $\begin{array}{l}80^{\circ} \mathrm{G} \\
\mathrm{HcL}\end{array}$ & $\begin{array}{l}15 \text { 分 } \\
20 \%\end{array}$ & $922 \gamma$ & $\begin{array}{l}80 \% \\
\mathrm{HcL}\end{array}$ & $\begin{array}{l}15 \text { 分 } \\
20 \%\end{array}$ & $792 \gamma$ \\
\hline $\begin{array}{l}80^{\circ} \mathrm{G} \\
\mathrm{HcL}\end{array}$ & $\begin{array}{l}15 \text { 分 } \\
30 \%\end{array}$ & $776 r$ & $\begin{array}{l}80^{\circ} \mathrm{C} \\
\mathrm{HcL}\end{array}$ & $\begin{array}{l}15 \text { 分 } \\
30 \%\end{array}$ & $785 \gamma$ \\
\hline $\begin{array}{c}100^{\circ} \mathrm{C} \\
\mathrm{HcL}\end{array}$ & $\begin{array}{l}15 \text { 分 } \\
10 \%\end{array}$ & $834 r$ & $\begin{array}{c}100^{\circ} \mathrm{C} \\
\mathrm{HcL}\end{array}$ & $\begin{array}{l}15 \text { 分 } \\
10 \%\end{array}$ & $620 \gamma$ \\
\hline
\end{tabular}

(DEHYDROISOANDROSTERONE.ANDROSTERONE.1000くよりの回收率)

15分にて dehydroisoandrosterone ば992r，androsterone 法792rの最高値を示したのでしの方法によつた。

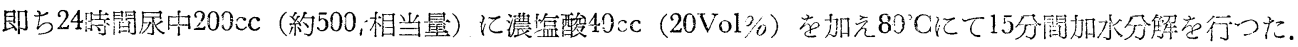

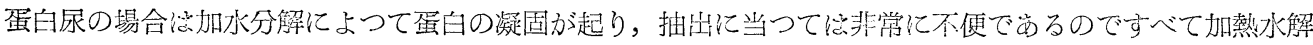

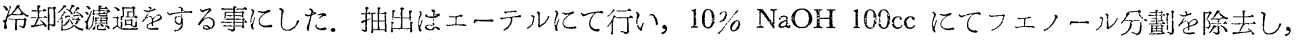

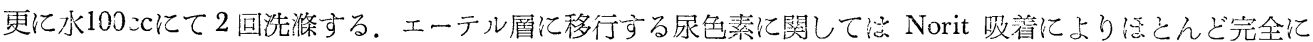

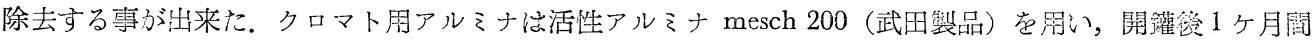
desicater 中に保肎したものか，或心恼新日アルミナを混合して使胃した，活些アルミナ1.3g を科量しベン ゼンに浮遊充猉するときは aluminacolumn は12cmの高さとなる，次いでェーテル抽出物の蒸発残淔を1cc のベンゼンに溶解してクロマト管に展開し，40－45 mm Hg の陽圧を加え溶出を行つた，溶煤䟴言と溶出速 度に関しては表 2 の如くエタノール濃复を多くする事により， dehydroisoandrosterone 及び androsterone 共

表 2 溶媒濃度と溶出速度

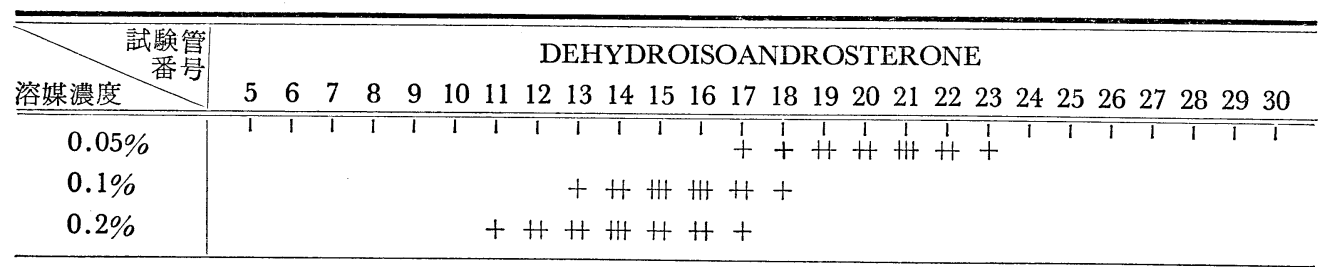

ANDROSTERONE

\begin{tabular}{|c|c|}
\hline $\begin{array}{l}0.1 \% \\
0.2 \% \\
0.3 \%\end{array}$ & $\begin{array}{l}+H+H H+H+ \\
+H+H+H+H+H+H+H\end{array}$ \\
\hline $\begin{array}{l}0.1 \% \\
0.2 \%\end{array}$ & $+H+H+H+$ \\
\hline 番号 & $\begin{array}{lllllllllllllllllllllllllllllll}5 & 6^{1} & 7 & 1 & 1 & 1 & 1 & 9^{1} & 10 & 11 & 12 & 1 & 1 & 1 & 1 & 1 & 1 & 1 & 1 & 1 & 1 & 1 & 1 & 1 & 1 & 1 & 1 & 1 & 1 & 1 & 1 \\
\end{array}$ \\
\hline
\end{tabular}

に早く溶出されるので留分劃の早期溶出と完全分離とを考慮して，0.1\%エタノール・ベンゼン $34 \mathrm{cc} 17$ 本， $0.2 \%$ エタノル・ベンゼン $30 \mathrm{cc} 15$ 本, $1 \%$ エタノール・ベンゼン $16 \mathrm{cc} 8$ 本, 次いで純エタノール $6 \mathrm{cc} 3$ 本, 合計 43 本にて溶出を終らせた. 各試耠管については Zimmerman 反応を行つた. 溶出部位に開してDingemanse

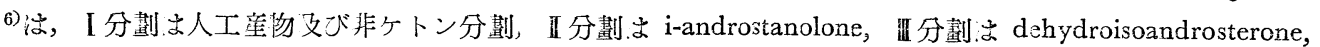

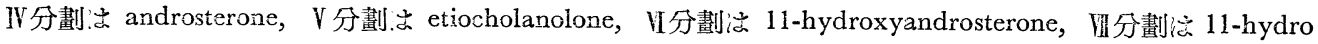
xyetiocholanolone と報告したが，私の実倹に於いても androsterone 及び dehydroisoandrosterone の負荷 試検並びに後述する testosterone 代謝率，更に各種ホルモンの投与実験によつて直接或いは閻接的に確諗す る事が出来た. 
尿中エストロゲンの定量としては，Jailer ${ }^{17)}$ 及び Finkelstein ${ }^{12)}$ の方法に従つて estrone・estradiol 分劃の抽 出を行い，不純螢光の補正はVerdhuis ${ }^{36)}$ そ従つた. 抽出に際してネフローゼ症候群患者の尿では Lipoiduria があるためか, Benzen に移行する物質が多く emulsion となるので Benzen を80ccに堌量して抽出を行い, それでも分離しない時は沈降管にて遠沈分離を行つた. 螢光比色計に八木式微量螢光比色計を使用し， lamp Filter としては450m $\mu$ ， interference Filter は525m ，更に補助 Filter として450m $\mu$ を使用した. 標準物質 は帝国臓器社製の estradiol を使用し，その 2 と比螢光をみた。回收率は estradiol $2 \gamma$ 添加により 70\%, estrone 2 添加にて $62 \%$ あつた.

\section{第3 章 尿中17KS分劃について}

\section{第 1 節 序}

$17 \mathrm{KS}$ 法 corticoid の側鎖が全く外された酸化物質で， $\mathrm{C}_{17}$ の位置に carboxyl 基を有するものの総称であ゙

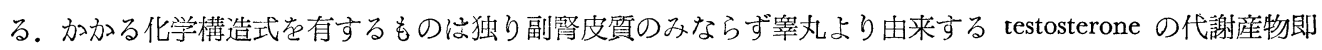
ち androsterone る又代表的なものである. 従つて本来の glucocorticoid 由来と考元られる 11-hydroxylated $17 \mathrm{KS}$ と, androgen 由来のものとを分離して測定する事牥各ステロイド代謝研究上極わて必要であり, 又臨

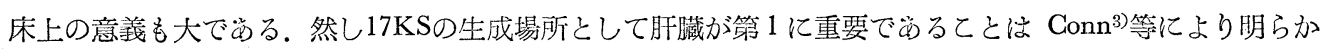
にされている如く，肝障碍時に尿中 $17 \mathrm{KS}$ が低值を示す報告沙非常に多い. 故に副整皮質機能及び性腺機能 を䫄う前に，肝に於ける cortisone, androgen の代謝が正常に行われているかどうか念頭に执いて孝えなけ

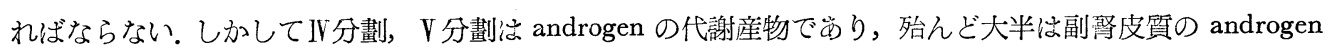
で睪丸及び卵巣より分泌される testosterone の代謝物结わずかで西ると考えられる。 III分劃の dehydroisoa

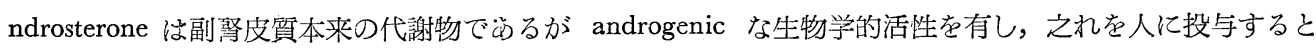
testosterone を投与した場合と同様汇主として androsterone と etiocholanolone が尿から単離されている。

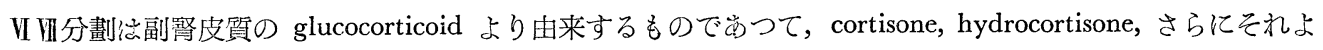
り変化した adrenosterone 加ら生ずると考えられている. cortisone の大量投与による代謝産物沁 11-hydro

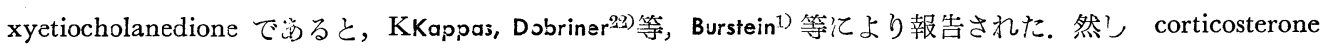
及び desoxycorticosterone (DOG) は17 Oxycorticoid に生体内で変化されない限り17KSになるてとはない。

\section{第 2 節 実 験 成 綪 \\ 第 1 項健康人}

健康男子 7 例纪於ける尿中 $17 \mathrm{KS}$ 分劃の成績哇 平均 $4.92 \mathrm{mg} / \mathrm{day}$, VI VII 分劃往 $1.57 \sim 5.86$ 平均 $3.79 \mathrm{mg} / \mathrm{day}$ と変動範囲结大きいが，IV V 分劃と III VIII 分劃 と

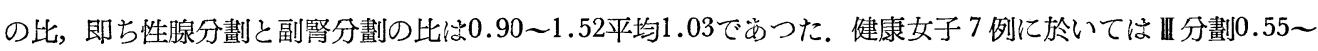
1.74 平均 $1.12 \mathrm{mg} /$ day. IV V 分劃㣙2.82 6.63平均 $3.70 \mathrm{mg} /$ day にて男子より絶対量では 1 日の排泄量が 1.22 $\mathrm{mg}$ 少ない.

又VIVII分劃住 2.06 - 5.14平均 $2.97 \mathrm{mg} /$ dayで副腎分劃も $0.82 \mathrm{mg}$ 少なく，IV V と III VI VI分劃との比では 0.51 ～1.60平均 0.93 と男女間に大差を認》ない，女子に於ける $17 \mathrm{KS} の$ pattern が男子とその比獄に於いて変ら

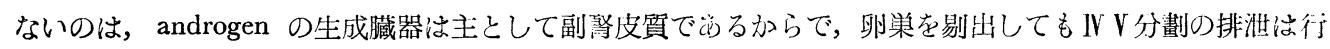
われている。

\section{第 2 項 堅 疾 患 者}

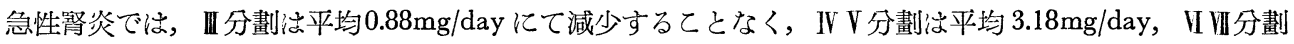

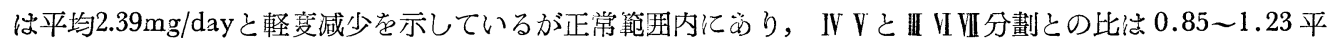

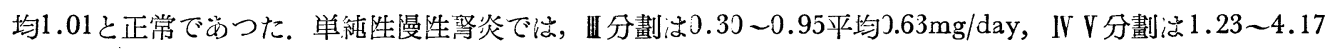
平均 $3.02 \mathrm{mg} / \mathrm{day}$, VI III分劃は $1.40 \sim 3.87$ 平均 $2.51 \mathrm{mg} / \mathrm{day}$ 亿て各分劃共絶対值に於いては軽变減少し，分劃 
表 3 健康者化於ける $17 \mathrm{KS}$ 分劃測定值

\begin{tabular}{|c|c|c|c|c|c|c|c|c|}
\hline \multicolumn{9}{|c|}{ （健 康 男 子） } \\
\hline Subject & $\underset{(\mathrm{mg})}{\mathrm{I}}$ & $\underset{(\mathrm{mg})}{\text { II }}$ & $\underset{(\mathrm{mg})}{\text { III }}$ & $\begin{array}{r}\mathrm{IV}+\mathrm{V} \\
(\mathrm{mg})\end{array}$ & $\underset{(\mathrm{mg})}{\mathrm{VI}+\mathrm{WII}}$ & $\begin{array}{c}\text { VIII } \\
(\mathrm{mg})\end{array}$ & $\begin{array}{l}\text { Total } \\
17 \mathrm{ks} \\
(\mathrm{mg})\end{array}$ & $\frac{I V+V}{I I+U+M I}$ \\
\hline Y.I. 42才 & 1.10 & 0.13 & 1.69 & 4.72 & 3.54 & 0.12 & 11.4 & 0.90 \\
\hline Q.T. 58才 & 0.43 & 0.18 & 1.15 & 2.84 & 1.57 & 0.21 & 6.3 & 1.04 \\
\hline S.M. 46才 & 0.31 & 0.03 & 0.52 & 3.64 & 3.47 & 0.64 & 8.6 & 0.91 \\
\hline T.I. 20才 & 0.27 & 0.00 & 0.48 & 3.75 & 3.60 & 0.22 & 8.4 & 0.92 \\
\hline L.A. 18才 & 0.47 & 0.04 & 0.79 & 6.84 & 2.70 & 0.06 & 12.4 & 1.52 \\
\hline N.O. 24才 & 0.94 & 0.57 & 1.82 & 6.74 & 4.84 & 0.33 & 15.1 & 1.01 \\
\hline K.O. 31 才 & 0.93 & 0.29 & 0.44 & 5.88 & 5.86 & 0.06 & 13.5 & 0.93 \\
\hline 変動 範 囲 & $0.27 \widetilde{1.10}$ & $0-0.57$ & $\begin{array}{r}0.48 \sim \\
1.82\end{array}$ & $\begin{array}{r}2.84 \sim \\
6.84 \\
\end{array}$ & $1.57 \widetilde{5.86}$ & $\begin{array}{r}0.12-64 \\
0.64\end{array}$ & $6.3 \sim 15.1$ & $0.90 \sim 1.52$ \\
\hline 均 & 0.64 & 0.18 & 0.98 & 4.92 & 3.79 & 0.24 & 10.8 & 1.03 \\
\hline （健 康 & 女 子 & & & & & & & \\
\hline Y.T. 20才 & 0.81 & 0.10 & 1.30 & 3.60 & 2.80 & 0.09 & 8.6 & 0.70 \\
\hline T.K. 30才 & 0.23 & 0.05 & 0.64 & 3.75 & 2.06 & 0.10 & 6.8 & 1.48 \\
\hline Q.T. 47才 & 0.31 & 0.08 & 0.64 & 2.97 & 5.14 & 0.76 & 9.8 & 0.51 \\
\hline T.M. 22才 & 1.30 & 0.75 & 1.74 & 2.82 & 2.06 & 0.23 & 10.9 & 0.74 \\
\hline M.O. 26才 & 0.64 & 0.58 & 1.46 & 3.50 & 3.15 & 0.32 & 9.2 & 0.66 \\
\hline I.N. 29才 & 0.31 & 0.09 & 0.55 & 3.07 & 3.03 & 0.10 & 7.2 & 0.85 \\
\hline Y.N. 18才 & 0.68 & 0.20 & 1.53 & 6.63 & 2.62 & 0.83 & 12.6 & 1.60 \\
\hline 変 動 範 团 & $\begin{array}{r}0.23 \sim \\
1.30\end{array}$ & $\begin{array}{r}.05 \sim \\
0.75\end{array}$ & $\begin{array}{r}0.55- \\
1.74\end{array}$ & $\mid \begin{array}{r}2.82 \widetilde{6.63} \\
\end{array}$ & $\begin{array}{r}2.06 \sim 5.14 \\
\end{array}$ & $\begin{array}{r}0.09-0.83 \\
0\end{array}$ & $\begin{array}{r}6.8 \sim 12.6 \\
\end{array}$ & $0.51 \sim 1.60$ \\
\hline 平 & 0.47 & 0.27 & 1.12 & 3.70 & 2.97 & 0.35 & 9.29 & 0.93 \\
\hline
\end{tabular}

表 4 䭱疾患者の $17 \mathrm{KS}$ 分劃測定値（その1）

\begin{tabular}{|c|c|c|c|c|c|c|c|c|c|c|}
\hline \multicolumn{11}{|c|}{ （急 性 腎 炎） } \\
\hline Subject & tion & $\underset{(\mathrm{mg})}{\mathrm{I}}$ & $\underset{(\mathrm{mg})}{\mathrm{II}}$ & $\underset{(\mathrm{mg})}{\text { III }}$ & $\left|\begin{array}{c}1 V+V \\
(m g)\end{array}\right|$ & $\mid \begin{array}{l}\mathrm{I}+\mathrm{VII} \\
(\mathrm{mg})\end{array}$ & $\begin{array}{c}\text { VIII } \\
(\mathrm{mg})\end{array}$ & $\begin{array}{l}\text { Total } \\
(\mathrm{mg})\end{array}$ & $\frac{\mathrm{IV}+\mathrm{V}}{\mathrm{II}+\mathrm{V}+\mathrm{VII}}$ & 倩 \\
\hline T.O. 우 & $25 才$ & 0.84 & 1.18 & 0.87 & 3.56 & 3.01 & 0.29 & 9.75 & 0.85 & $\begin{array}{l}\text { B.D. } 145 \sim 90 \\
\text { 尿蛋白 }(+) \text { 赤血球 }(+H)\end{array}$ \\
\hline Y.K. 우 & $18 才$ & 0.28 & 0.14 & 0.60 & 3.18 & 2.95 & 0.21 & 7.26 & 0.95 & $\begin{array}{l}\text { B.D. } 132 \sim 98 \\
\text { 尿蛋白 }(+) \text { 浮腫 }(+)\end{array}$ \\
\hline L.M. 우 & 17才 & 0.65 & 0.08 & 0.94 & 2.67 & 1.23 & 0.28 & 5.85 & 1.23 & $\begin{array}{l}\text { B.D. } 143 \sim 75 \\
\text { 尿蛋白 }(+) \text { 赤血球 }(+t)\end{array}$ \\
\hline 平 & 均 & 0.59 & 0.47 & 0.80 & 3.13 & 2.38 & 0.26 & 7.64 & 1.01 & \\
\hline \multicolumn{11}{|c|}{ （単純性慢性粲炎） } \\
\hline S.H. 占 & 29才 & 0.08 & 0 & 0.30 & 0.23 & 3.87 & 0.12 & 7.10 & 0.65 & $\begin{array}{l}\text { B.D. } 124 \sim 79 \\
\text { 尿蛋白 }(+t) \text { 浮腫 }(-)\end{array}$ \\
\hline Y.N. $\hat{o}$ & 37 才 & 0.74 & 0.72 & 0.95 & 4.17 & 2.56 & 0.64 & 9.80 & 1.18 & $\begin{array}{l}\text { B.D. } 120-70 \\
\text { 尿蛋白 }(+) \text { 浮腫 }(-)\end{array}$ \\
\hline S.L. 우 & 39 才 & 0.38 & 0.08 & 0.36 & 1.23 & 2.22 & 0 & 4.27 & 0.47 & $\begin{array}{l}\text { B.D. } 130 \sim 95 \\
\text { 尿蛋白 }(+) \text { 浮腫 }(+)\end{array}$ \\
\hline K.T. 우 & $28 才$ & 0.09 & 0.34 & 0.92 & 3.95 & 1.40 & 0.50 & 7.22 & 1.70 & $\begin{array}{l}\text { B.D. } 118 \sim 69 \\
\text { 尿蛋白 }(+) \text { 浮腫 }(+)\end{array}$ \\
\hline 平 & 均 & 0.32 & 0.28 & 0.63 & 3.02 & 2.51 & 0.32 & 7.09 & 1.00 & \\
\hline
\end{tabular}


（高血圧性慢性粲炎）

\begin{tabular}{|c|c|c|c|c|c|c|c|c|c|c|c|}
\hline T.O. & $\hat{o}$ & 18才 & 0.09 & 0.02 & 0.35 & 1.74 & 0.86 & 0.05 & 3.11 & 1.96 & $\begin{array}{l}\text { B.D. } 159 \sim 90 \\
\text { 尿蛋白 }(+) \text { 浮腫 }(+)\end{array}$ \\
\hline Y.F. & 우 & 35才 & 0 & 0.05 & 0.20 & $1 . .13$ & 0.36 & 0.05 & 1.79 & 2.01 & $\begin{array}{l}\text { B.D. } 185-115 \\
\text { 尿蛋白 }(+) \text { 浮腫 }(+)\end{array}$ \\
\hline O.T. & $\hat{\delta}$ & $42 才$ & 0.92 & 0.08 & 0.84 & 2.77 & 2.98 & 0.65 & 8.24 & 0.72 & $\begin{array}{l}\text { B.D. } 170-110 \\
\text { 尿蛋白 }(+) \text { 浮腫 }(-)\end{array}$ \\
\hline 平 & & 均 & 0.34 & 0.05 & 0.46 & 1.88 & 1.40 & 0.25 & 4.38 & 1.56 & \\
\hline
\end{tabular}

(続 発性萎縮䈪)

\begin{tabular}{|c|c|c|c|c|c|c|c|c|c|c|c|}
\hline K. Y . & $\hat{o}$ & 58才 & 0.50 & 0.05 & 0.37 & 2.65 & 1.75 & 0.74 & 6.06 & 1.24 & $\begin{array}{l}\text { B.D. } 180 \sim 135 \\
\text { 尿量 } 1400 \mathrm{cc}\end{array}$ \\
\hline$Y . Y$. & 우 & 30 才 & 0.05 & 0.04 & 0.15 & 0.29 & 0.31 & 0.03 & 0.87 & 0.63 & $\begin{array}{l}\text { B.D. } 120-95 \text { 㽷量 } \\
(400 \text { c) } R-N 75 \mathrm{mg} / \mathrm{dl}\end{array}$ \\
\hline $\mathrm{S} . \mathrm{K}$ & 우 & 70才 & 0 & 0.01 & 0.03 & 0.43 & 0.33 & 0.06 & 0.90 & 1.27 & 尿量 $(600 \mathrm{cc}$ ) \\
\hline 平 & & 均 & 0.18 & 0.03 & 0.18 & 1.12 & 0.80 & 0.28 & 2.61 & 1.05 & \\
\hline
\end{tabular}

（尿 毒症）

\begin{tabular}{lll|l|l|l|l|l|l|l|l|l|}
\hline T.W. ㅇ & 42 才 & 0.05 & 0 & 0.02 & 0.07 & 0.49 & 0.02 & 0.64 & 0.14 & $\begin{array}{l}\mathrm{B} . \mathrm{D} .160 \sim 135 \\
\mathrm{R}-\mathrm{N} \text { 90mg/d }\end{array}$ \\
\hline
\end{tabular}

表 5 ネフローゼ症候群㭧者に於ける $17 \mathrm{KS}$ 分劃測定值

(腎疾患その 2 )

\begin{tabular}{|c|c|c|c|c|c|c|c|c|c|c|}
\hline Subject & on & $\underset{(\mathrm{mg})}{\mathrm{I}}$ & $\underset{(\mathrm{mg})}{\mathbb{I I}}$ & $\underset{(\mathrm{mg})}{\mathbb{I I I}}$ & $\begin{array}{c}1 V+V \\
(\mathrm{mg})\end{array}$ & $\begin{array}{l}\mathrm{VI}+\mathrm{VI} \\
(\mathrm{mg})\end{array}$ & $\underset{(\mathrm{mg})}{\mathrm{VIII}}$ & $\begin{array}{l}\text { Total } \\
(\mathrm{mg})\end{array}$ & $\frac{I V+V}{U+V+V I}$ & 考 \\
\hline H.K. 令 & 28才 & 0 & 0.05 & 0.20 & 0.69 & 0.78 & 0.13 & 1.85 & 0.70 & $\begin{array}{l}\text { 尿蛋白 }(H+H) \text { 浮腫 }(H) \\
\text { 尿量 }(400)\end{array}$ \\
\hline T.W. 余 & 24才 & 0.07 & 0.03 & 0.10 & 0.55 & 0.52 & 0.01 & 1.28 & 0.89 & 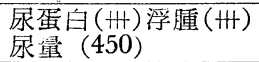 \\
\hline H.K. 令 & 38才 & 0 & 0.02 & 0.03 & 0.85 & 1.14 & 0.02 & 2.06 & 0.73 & $\begin{array}{l}\text { 尿蛋白 }(H+) \text { 浮腫 }(-) \\
\text { 水量 }(600)\end{array}$ \\
\hline N.U. 令 & 17才 & 0.07 & 0 & 0.15 & 0.31 & 0.53 & 0.02 & 1.08 & 0.46 & $\begin{array}{l}\text { 尿蛋白 }(+) \text { 浮腫 }(+) \\
\text { 尿量 }(420)\end{array}$ \\
\hline Y.S. 占 & 13才 & 0.09 & 00.1 & 0.21 & 0.81 & 0.30 & 0.03 & 0.82 & 0.35 & $\begin{array}{l}\text { 尿蛋白 }(\mathrm{H}) \text { 浮腫 }(\mathrm{H}) \\
\text { 尿量 }(150)\end{array}$ \\
\hline J.A. 우 & 18才 & 0.05 & 0.01 & 0.30 & 1.47 & 1.16 & 0.04 & 3.03 & 1.01 & $\begin{array}{l}\text { 尿蛋白 }(++) \text { 浮腫 }(-) \\
\text { 尿量 }(800)\end{array}$ \\
\hline Y.M. 우 & 31 才 & 0.17 & 0.07 & 0.45 & 1.43 & 1.24 & 0.07 & 3.43 & 0.84 & $\begin{array}{l}\text { 尿蛋白 }(H) \text { 浮腫 }( \pm) \\
\text { 尿量 }(850)\end{array}$ \\
\hline Y.F. 우 & $19 才$ & 0.34 & 0.14 & 0.52 & 0.97 & 1.75 & 0.05 & 3.77 & 0.34 & $\begin{array}{l}\text { 尿蛋白 }(+t) \text { 浮腫 }( \pm) \\
\text { 水量 }(640)\end{array}$ \\
\hline M. I. 令 & 25才 & 0.09 & 0.12 & 1.02 & 1.51 & 1.53 & 0.25 & 4.52 & 0.59 & $\begin{array}{l}\text { 尿蛋白 }(+ \text { 浮腫 }( \pm) \\
\text { 尿量 }(1080)\end{array}$ \\
\hline S.A. 孛 & 18才 & 0.52 & 0.18 & 0.41 & 3.04 & 1.78 & 0.31 & 6.24 & 1.39 & \multirow[t]{2}{*}{$\begin{array}{l}\text { 尿蛋白 }(H) \text { 浮腫 }(-) \\
\text { 水量 }(820)\end{array}$} \\
\hline 変 動 範 & 囲 & $\mid 0 \sim 0.52$ & $\overline{0 \sim}$ & $\begin{array}{r}0.03 \sim \\
1.02\end{array}$ & $\begin{array}{r}0.18 \approx 0 \\
3.04\end{array}$ & $\begin{array}{r}0.30 \sim 0 \\
1.78\end{array}$ & $\begin{array}{c}0.01 \sim \\
0.31\end{array}$ & $\begin{array}{r}0.82 \sim \\
6.24\end{array}$ & $0.35 \sim 1.39$ & \\
\hline 平 & 均 & 0.14 & 0.06 & 0.34 & 1.10 & 1.07 & 0.10 & 2.81 & 0.74 & \\
\hline
\end{tabular}

比で经変動範囲が大きく 0.47 1.70平均1.00であり，健康者と比較して各分劃つ balance が茝いと思われ

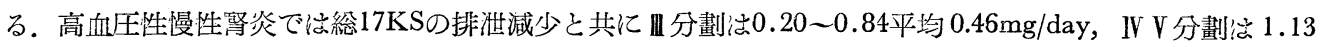
～2.77平均 $1.88 \mathrm{mg} / \mathrm{day}$ ＶIIII分劃岕0.36 2.98平均 $1.40 \mathrm{mg} / \mathrm{day}$ と各分劃共更に減少し，その比於いて心 0.72 2.01 と広汎な変動範井を示すが，平均1.56で副㛑性分劃刀方が比较的著明に減少する．又筒炎の未期 続発性萎縮腎ではIVV分劃，目 VIVI分劃は共に著咸を示すが，症例 1 は未だ代償期にて筒機能もよく保たれ 
多尿の時期であつたので正常値に近い值を示した，尿毒症の 1 例で空総 $17 \mathrm{KS}$ の著減と共に各分劃共殆んど

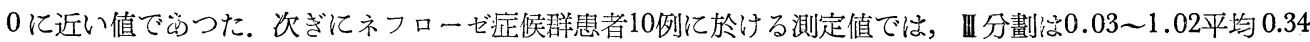

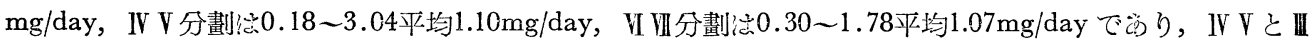

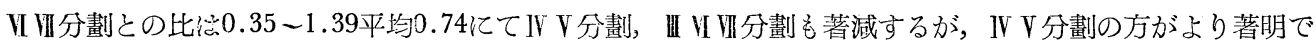

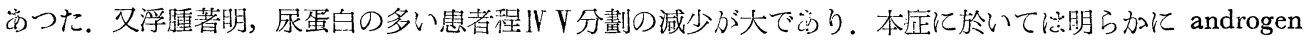
及び glucocort icoid の減少並びにその代謝が弱まつているものと考えられる.

\section{第 3 項＼cjkstart高血圧病及び內分泌疾患者}

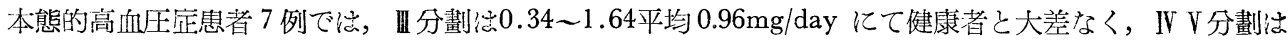

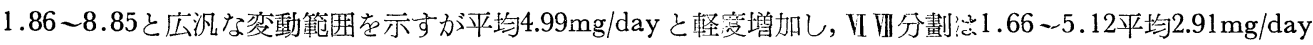

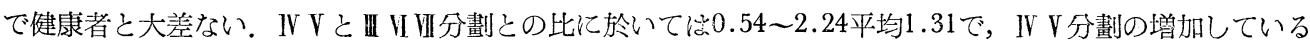

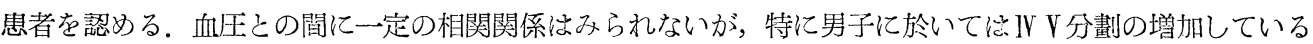

表 6 本態的高血圧症患者 $17 \mathrm{KS}$ 分劃

\begin{tabular}{|c|c|c|c|c|c|c|c|c|c|c|}
\hline${ }_{\text {Subject }}^{\text {Fr }}$ & tion & $\begin{array}{c}\mathrm{I} \\
(\mathrm{mg})\end{array}$ & $\underset{(\mathrm{mg})}{I}$ & $\begin{array}{c}\text { 甚 } \\
(\mathrm{mg})\end{array}$ & $\begin{array}{r}\mathrm{IV}+\mathrm{V} \\
(\mathrm{mg})\end{array}$ & $\begin{array}{l}\mathrm{II}+\mathrm{WI} \\
(\mathrm{mg})\end{array}$ & $\begin{array}{c}\text { VIII } \\
(\mathrm{mg})\end{array}$ & $\begin{array}{l}\text { Total } \\
(\mathrm{mg})\end{array}$ & $\frac{I V+V}{U+U+H}$ & 備 \\
\hline S.N. 令 & 48才 & 0.36 & 0.58 & 0.55 & 7.68 & 5.12 & 0.20 & 14.5 & 1.35 & $\begin{array}{l}\text { B.D. } 185 \sim 130 \\
\text { 尿蛋白 }(+)\end{array}$ \\
\hline $\mathrm{K} . \mathrm{H}$. 令 & 21才 & 0.29 & 0.12 & 1.49 & 4.36 & 1.66 & 0.16 & 8.3 & 1.35 & $\begin{array}{l}\text { B.D. } 150 \sim 75 \\
\text { 尿蛋白 }(-)\end{array}$ \\
\hline S.O. & 44才 & 0.11 & 0.28 & 1.64 & 8.85 & 2.31 & 0.89 & 14.2 & 2.24 & $\begin{array}{l}\text { B.D. } 190 \sim 110 \\
\text { 尿蛋白 }(-)\end{array}$ \\
\hline L.O. & 62才 & 0.09 & 0.12 & 0.87 & 4.05 & 2.03 & 0.79 & 7.95 & 1.40 & $\begin{array}{l}\text { B.D. } 2214-120 \\
\text { 尿蛋白 }(-)\end{array}$ \\
\hline M.K. 오 & 34 才 & 0.52 & 0 & 1.02 & 5.04 & 3.14 & 0.18 & 9.82 & 1.21 & $\begin{array}{l}\text { B.D. } 210-120 \\
\text { 尿蛋白 }(+)\end{array}$ \\
\hline M.H. & 64 才 & 0.19 & 0.08 & 0.34 & 1.86 & 3.12 & 0.25 & 5.84 & 0.54 & $\begin{array}{l}\text { B.D. } 186-92 \\
\text { 㽷蛋白 }(-)\end{array}$ \\
\hline U.Y. 오 & 47 才 & 0.14 & 0.28 & 0.79 & 3.14 & 2.99 & 0.31 & 7.65 & 1.09 & $\begin{array}{l}\text { B.D. } 178 \sim 10 \\
\text { 尿蛋白 }(-)\end{array}$ \\
\hline 平 & 均 & 0.24 & 0.21 & 0.96 & 4.99 & 2.91 & 0.25 & 9.46 & 1.31 & \\
\hline
\end{tabular}

悪性高血圧症患者 $17 \mathrm{KS}$ 分劃

\begin{tabular}{lll|l|l|l|l|l|l|l|l|l}
\hline T.K. 占 & $41 才$ & 0.06 & 0.13 & 0.76 & 2.57 & 1.25 & 0.37 & 5.12 & 1.28 & $\begin{array}{c}\text { B.D. } \\
\text { 白(H) R 7-N45 } 135 \text { 尿蛋 }\end{array}$ \\
\hline
\end{tabular}

表 7 内分泌疾患者の $17 \mathrm{KS}$ 分劃測定值

\begin{tabular}{|c|c|c|c|c|c|c|c|}
\hline \multicolumn{8}{|c|}{ （糖疗病惥者） } \\
\hline Subject & $\begin{array}{l}\mathrm{I} \perp \mathrm{II} \\
(\mathrm{mg})\end{array}$ & $\underset{(\mathrm{mg})}{\text { III }}$ & $\begin{array}{c}\mathrm{IV}+\mathrm{V} \\
(\mathrm{mg})\end{array}$ & $\underset{(\mathrm{mg})}{\mathrm{V}+\mathrm{VII}}$ & $\begin{array}{l}\text { VIII } \\
(\mathrm{mg})\end{array}$ & $\begin{array}{c}\text { TotallikS } \\
(\mathrm{mg})\end{array}$ & $\frac{\mathrm{J}+\mathrm{V}}{\mathrm{II}+\mathrm{VI}+\mathrm{VII}}$ \\
\hline G.M. 令 42 才 & 0.21 & 0.48 & 2.26 & 3.96 & 0.24 & 7.15 & 0.51 \\
\hline J.A. 令 57才 & 1.84 & 1.29 & 4.56 & 6.22 & 0.11 & 14.1 & 0.60 \\
\hline M. I. 令 38 才 & 0.34 & 1.00 & 4.30 & 4.74 & 0.89 & 11.27 & 0.75 \\
\hline 平 & 0.79 & 0.92 & 3.71 & 4.97 & 0.41 & 10.81 & 0.62 \\
\hline \multicolumn{8}{|c|}{ （バセドウ氏病） } \\
\hline Y.M. 우 57才 & 0.44 & 0.46 & 1.26 & 1.84 & 0.26 & 4.24 & 0.58 \\
\hline G. I. & 1.47 & 1.01 & 1.01 & 1.87 & 0.40 & 5.76 & 0.38 \\
\hline
\end{tabular}




\begin{tabular}{|c|c|c|c|c|c|c|c|c|}
\hline \multicolumn{9}{|c|}{ (アクロメガリー) } \\
\hline $\mathrm{T} \cdot \mathrm{M}$ & 令 26才 & 0.21 & 0.98 & 7.19 & 9.25 & 1.80 & 19.50 & 0.70 \\
\hline \multicolumn{9}{|c|}{ （女子去勢者 Oophorohysterectomy） } \\
\hline $\mathrm{K} . \mathrm{K}$. & 우 49才 & 0.23 & 0.82 & 0.59 & 3.40 & 0.49 & 5.46 & 0.14 \\
\hline
\end{tabular}

傾向がある．悪性高血圧症の 1 例ではIV V 分劃の軽度娍少，VIII分劃の減少を示した．

内分琅疾患者としてバセドウ氏病では 2 例共に総 $17 \mathrm{KS}$ 纷軽度減少し，分劃比では $0.58 ， 0.38$ とIV 分劃 の減少が著明であつた．Akromegalie の1 例でに総17KSの堌加と共にWV分劃及びVV分劃!著昵に堌加 したが，III分劃は大体正常であつた，卵巣剔出による女子去勢者で内分泌失調症を訴える患者の 1 例では，

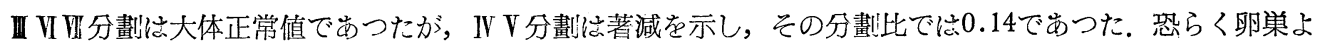
り分泌される androgen 、極めて少ないものと考えられるが，乙の症例では顽髪の脱落，皮膚の乾燥等内分

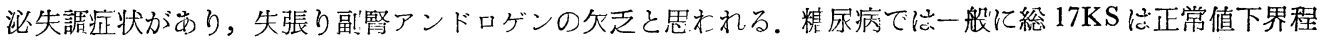

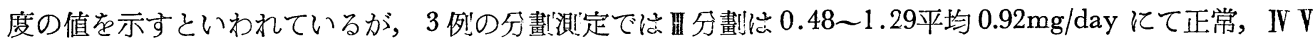

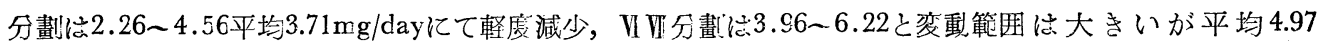
$\mathrm{mg} /$ day と健康者よりわずかに増加の傾向が見られる。

\section{第 4 項 ネフローゼ症候群の経過と17KS分劃}

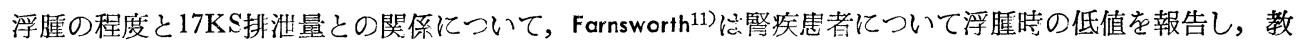
室下村 ${ }^{42)}$ 《浮腫消退によつてはじめて排泄量が境加すると述へている。私はネフローゼ症候群患者 2 例につ いて，その経過を追及し，全く治療していない浮栕著明な入院時と，症状がやや安定した時，及び prednis one 療法等により経過好軾䌊解した時の 3 段階にこいて尿中 $17 \mathrm{KS}$ 分劃浿定を行い，浖住体重，尿量，尿蛋

表 8 ネフローゼ症候群患者の経過と17KS分劃

\begin{tabular}{|c|c|c|c|c|c|c|c|c|c|c|c|}
\hline \multicolumn{12}{|c|}{ No. 1} \\
\hline & & $\begin{array}{c}\text { III } \\
(\mathrm{mg})\end{array}$ & $\begin{array}{l}\mathrm{V}+\mathrm{V} \\
(\mathrm{mg})\end{array}$ & $\begin{array}{l}\mathrm{VI}+\mathrm{VI} \\
(\mathrm{mg})\end{array}$ & $\begin{array}{l}\text { Total } \\
17 \mathrm{KS} \\
\text { (mg) }\end{array}$ & $\frac{\mathrm{J}+\mathrm{V}}{\mathrm{WI}+\mathrm{VI}+\mathrm{W}}$ & $\begin{array}{c}\text { 尿 }(\mathrm{cc})^{\text {量 }} \\
\end{array}$ & 体 重 & $\begin{array}{c}\text { 尿蛋白 } \\
\text { 末吉 } \\
(\%)\end{array}$ & $\begin{array}{l}\text { 血 清 } \\
\begin{array}{c}\text { フルブミ゙ } \\
(\mathrm{g} / \mathrm{dl})\end{array}\end{array}$ & 備 考 \\
\hline H.K. & 今 28才 & 0.20 & 0.69 & 0.78 & 1.85 & 0.72 & 450 & 42 & 12 & 1.82 & \\
\hline "I & & 0.03 & 0.85 & 1.14 & 2.06 & 0.73 & 600 & 42.5 & 10 & & \\
\hline "I & （軽快） & 0.37 & 1.65 & 2.08 & 4.35 & 0.68 & 950 & 38.5 & 1.5 & 3.06 & $\begin{array}{l}\text { プレドニン } \\
\text { 使 用 後 }\end{array}$ \\
\hline \multicolumn{12}{|c|}{ No. 2} \\
\hline Y.F. & 우 19才 & 0.28 & 0.95 & 1.24 & 2.83 & 0.63 & 400 & 55 & 13 & & \\
\hline 11 & & 0.52 & 0.97 & 1.75 & 3.77 & 0.43 & 600 & 54 & 11 & 0.97 & \\
\hline "I & （軽快） & 0.68 & 1.88 & 1.95 & 5.12 & 0.71 & 1300 & 52 & 0 & 2.78 & $\begin{array}{l}\text { プレドニン } \\
\text { 使 用 後 }\end{array}$ \\
\hline
\end{tabular}

白量，血清アルブミン量と比較検討してみたとてろ，浮腫体重の減少，尿蛋白量の減少，血清アルブミンの

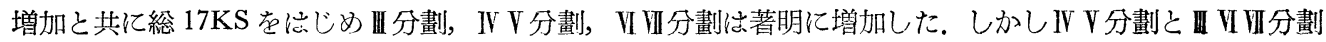
との比仿学末り著変がなか力っ。

\section{第 5 項 $\quad A C T H$ 投与実験}

ネフローゼ症候群息者に Armour 社製 ACTH 1 日量 $25 \mathrm{mg}$ を 3 回に分け 8 時間間隔で静脈内注射を 2 日 間投与し，その後の筑 1 日目尿及び第 2 日目尿について注射前と比較してみたが，総 $17 \mathrm{KS}$ は注射前の 3.68 $\mathrm{mg}$ 加巨注射後第 1 日目 $6.9 \mathrm{gmg}$, 第 2 日目 $6.34 \mathrm{mg} / \mathrm{day}$ と堌加し，VI分劃は第 1 日目に於いて約 3 倍程度に 
著明な増加を示し，又VV分劃も増加した，第 2 日目尿に於いては第 1 日目尿よりは軽度减少したが注射前

図 2 ACTH投与実験（ネフローゼ症候群患者） ACTH 25mg 青彩注 2日间 (18 t 9 )
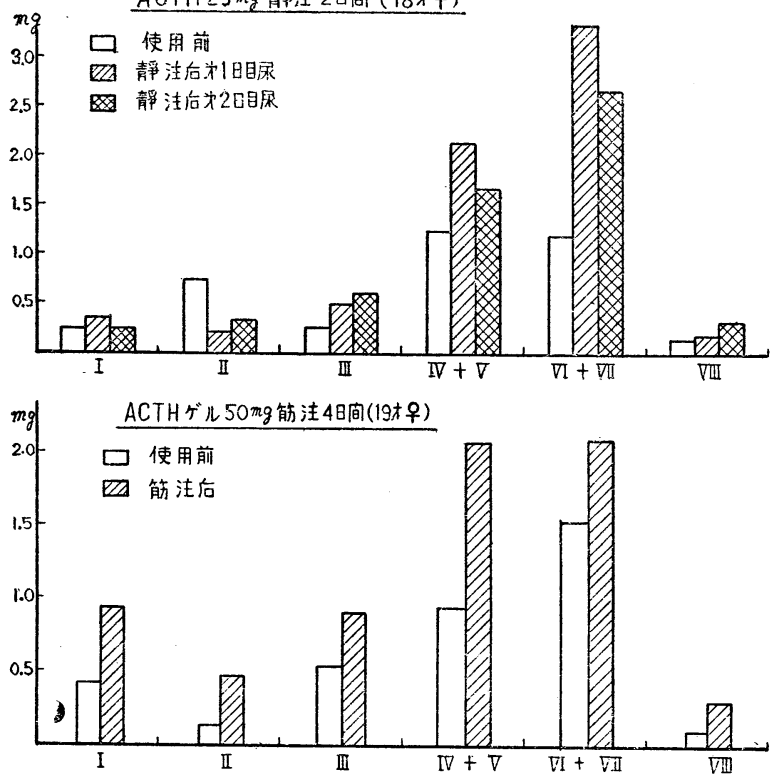

に比べるとVIVII分劃ばるが増加 している。然し 更分劃はわずが堌 したのみにて，I分劃空かえつて減 少した，健康者に於いて ACTH 支配により副腎皮質束状層より glucocorticoid が分泌せられる事惊 多くの人々により認められているが， ネフローゼ症候群患者に於いても副 腎皮質機能の活性化が窅われる，然 しIV V 分劃も増加したのは $\mathrm{ACTH}$ 投与により androgen 系ステロイド 代謝にも急激な変化を来たしたもの として興味深い. Kappas ${ }^{22)}$ 等によれ ばACTH投与によつて androsterone や etiocholanolone が堌加するのは， 副堅皮質より分泌されるtestosterone から $4^{4}$ androstane 3,17 dione の增 加によるためであり, androsterone と etiocholanolone の增加する割合 住一定していたと報告している．次

ぎにネフローゼ症候群患者に ACTH-Gel 1 日50mg，4 日間連続筋注を行つた前後の17KS分劃をみると， I 加ら珻迄の各分劃共增加を示し，総17KS

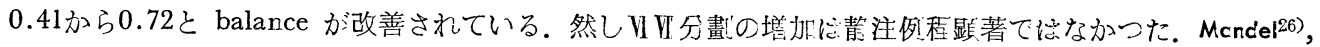

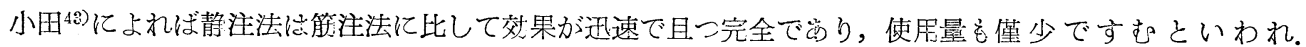

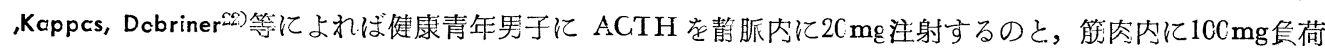
した場合と尿中17KSの 11-hydroxylated steroid の堌加に大体同様であつたと述べている。ネフローゼ症候 群患者に於いても失張り筋注に比較して静脈内負荷の場合が，VIII分劃の増加ば著明で施つた。

第 6 項 Testosterone

代謝率について

testosterone 在荷して尿中 に排泄される主な steroid に, androsterone $\measuredangle$ etiocholanolone でらると统早くから知られて いたが，1950年 Dobriner 等 testosterone を毎日90mgづつ正常 男子に45日閐投与し，全投与昜の 約 $50 \%$ が代謝物として排泄され， さらにその約半分 $20 \%$ が androst erone として, 㕛19\%が etiochol anolone として排泄され，残りの 僅丸な部分が ardrostandione と
表 9 Testosterone 代謝率

\begin{tabular}{|c|c|c|c|c|}
\hline \multicolumn{5}{|c|}{ 健康界子30才（エナルモン40mg筋注） } \\
\hline & $\begin{array}{c}W+\mathrm{V} \\
(\mathrm{mg})\end{array}$ & $\begin{array}{c}\text { 代謝率 } \\
(\%)\end{array}$ & $\mid \begin{array}{c}\text { Total17KS } \\
(\mathrm{mg})\end{array}$ & $\frac{J+V}{I I+V+V}$ \\
\hline 前 & 4.08 & & 10.66 & 0.85 \\
\hline 注射後第 1 日目尿 & 9.93 & 14.8 & 17.17 & 1.81 \\
\hline 注射後第 2 日目尿 & 6.86 & 7.0 & 15.3 & 0.98 \\
\hline 注射後第 4 日目尿 & 3.84 & 0 & 11.02 & 0.73 \\
\hline \multicolumn{5}{|c|}{ ネフローゼ症候群㭧者男子25才（エナルモン40mg筋注） } \\
\hline 注 & 1.26 & & 3.51 & 0.70 \\
\hline 注射後第 1 日目尿 & 3.98 & 6.8 & 6.52 & 1.46 \\
\hline 注射後穊 3 日目尿 & 2.93 & 4.2 & 5.64 & 1.31 \\
\hline 注射後第 4 日目尿 & 1.53 & 0.7 & 4.17 & 0.74 \\
\hline
\end{tabular}


etiocholanedione (1\%) 並びそ andrcstanediol と eticcholanediol (6\%) として讲泄されるととを証明し た. Fukushima12)等は testosterone の䈈店内大量 $(10 \mathrm{~cm})$ 及び小量 $(1 \mathrm{cmg})$ 投与に於ける代誴物を，第 1 日目尿及び第 2 日目尿よりクロマトグラフィーにて分離し，大最投与より小量の方が代謝率が高く，第 1 日

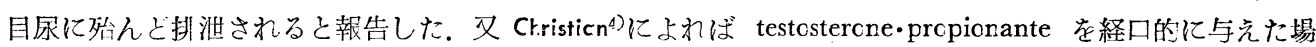

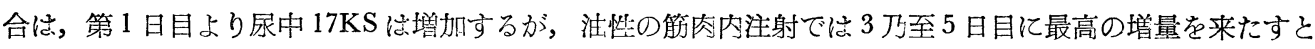
いう。私统健康者並びにネフローセ症候群鼻者男子に testosterone·propionate としてェナルモン $40 \mathrm{mg}$ を筋 注し，第 1 日目尿及び節 2 日目尿，更に第 4 日目尿について注射前と比較した。先づ健康者に於いては注射 前IV V分劃は $4.08 \mathrm{mg}$ であつたが，注射徐第 1 日目 $9.92 \mathrm{mg}$ ，代謝率 $14.8 \%$ ，第 2 日目 $6.86 \mathrm{mg} ，$ 代謝率7.0\%， 第 4 日目 $3.84 \mathrm{mg}$ ，代謝率 0 であつた。次ざにネフローゼ症候群患者に於いてい注射前 $\mathrm{N} V$ 分劃は $1.26 \mathrm{mg}$ で， 注射後第 1 日目 $3.98 \mathrm{mg}$ ，代謝率 $6.8 \%$ ，第 2 日目 $2.39 \mathrm{mg} ，$ 代謝率 $4.2 \%$ ，第 4 日目は $1.53 \mathrm{mg} て ゙$ 代舫率 $0.7 \%$

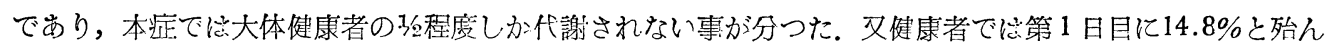

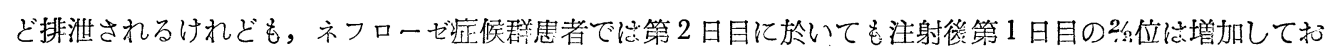
り，管 4 日目に於いても代謝率 $0.7 \%$ ，健康者に比して尿中に代謝されて来るのか遅いと思かれる，又N

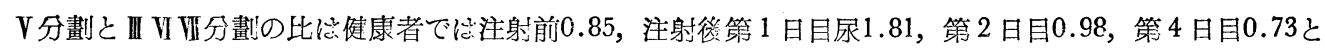

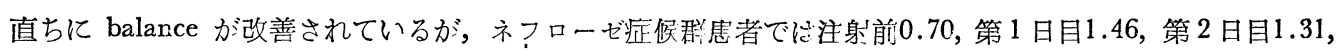
第4日目 0.74 と元にかえるのが遅いと思われる， testosterone 負荷後にVVII分劃か疃加するのは， testosterone 投与が下垂体に働き glucocorticoid 分泌の普加を来たしたものと考えられる。

\section{第3 節 小括}

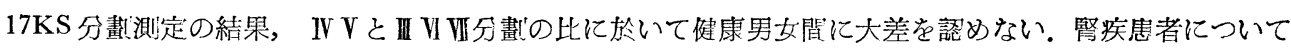

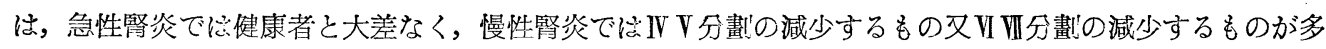

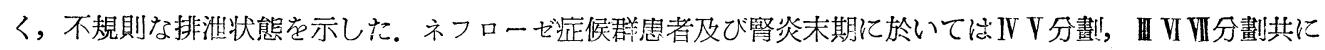
著明な排泄減少を示した，本態的高血圧症で涊特に男子の場合IV V分劃'の軽度堌加がみられた。 又内分泌疾

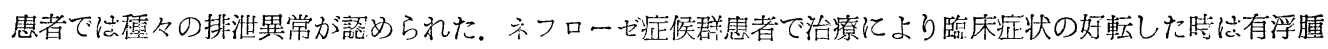

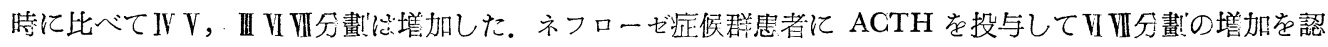

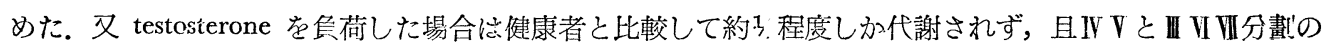
balance の改善访遅延した。

\section{第 4 章 尿中エストロゲンについて}

\section{第 1 節 序言}

尿中に排泄される estrogen として主要なもの结, estrone, estradiol, estriol の3つであり, しかも他のス テロイドホルモンに比へて非常に微量で，妊娠或いは病的状態を除いては1日量が $て$ 単位で算せられるに過 ぎない，その上女性にあつては月経週期と関連してその排泄量にかなりの変動がある。従つてその定量法は 微量を測定し得るもので, 日を追つて測定出来る程度に簡便なものでないと一般臨床に仙店用し難い. そと

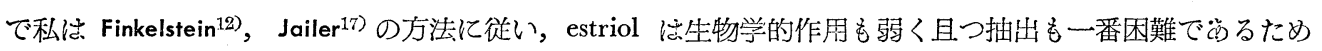
之を除去し, estrone, estradiol 分劃の抽出を行つて螢光比色法により測定した. 又不純螢光の補正住 Verdhuis 66)の方法に従つた。

\section{第 2 節 実 験 成 綪 \\ 第 1 項 健 康 者}

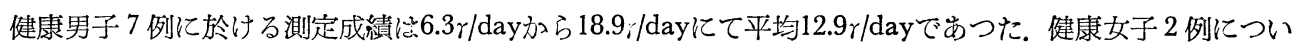

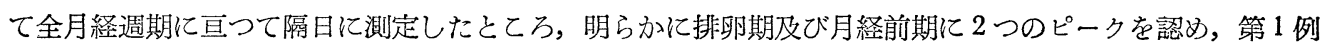

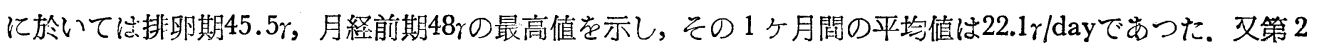


表 10 尿中 ESTROGENS (ESTRONE・ESTRADIOL 分劃) 排泄值

\begin{tabular}{|c|c|c|c|c|c|c|c|}
\hline \multicolumn{2}{|c|}{ 健 } & \multicolumn{2}{|l|}{ 男 } & \multicolumn{4}{|c|}{ ネフローゼ症候群患者男子 } \\
\hline Subject & Age & $\begin{array}{c}\text { Estrogens } \\
(\gamma)\end{array}$ & $\begin{array}{l}\text { 尿 }(\mathrm{cc}) \\
\text { 量 }\end{array}$ & Subject & Age & $\begin{array}{c}\text { Estrogens } \\
(\gamma)\end{array}$ & $\begin{array}{l}\text { 尿 量 } \\
\text { (cc) }\end{array}$ \\
\hline U.O. & 21 & 18.9 & 1400 & T.W. & 21 & 9.3 & 400 \\
\hline Y.M. & 24 & 17.4 & 1090 & M. S. & 18 & 10.4 & 500 \\
\hline T. I. & 25 & 8.5 & 1200 & $\mathrm{Y} . \mathrm{Y}$ & 28 & 4.6 & 650 \\
\hline K.O. & 31 & 16.4 & 1300 & Y.S. & 13 & 5.5 & 400 \\
\hline M. F. & 33 & 6.3 & 1500 & M. I . & 25 & 18.8 & 800 \\
\hline Y. I. & 41 & 12.6 & 900 & S.A. & 21 & 19.6 & 1100 \\
\hline M.M. & 44 & 10.4 & 1200 & H.K. & 26 & 7.2 & 900 \\
\hline 平均 & & 12.9 & & 平均 & & 10.8 & \\
\hline
\end{tabular}

図 3 ESTRONE・ESTRADIOL分劃
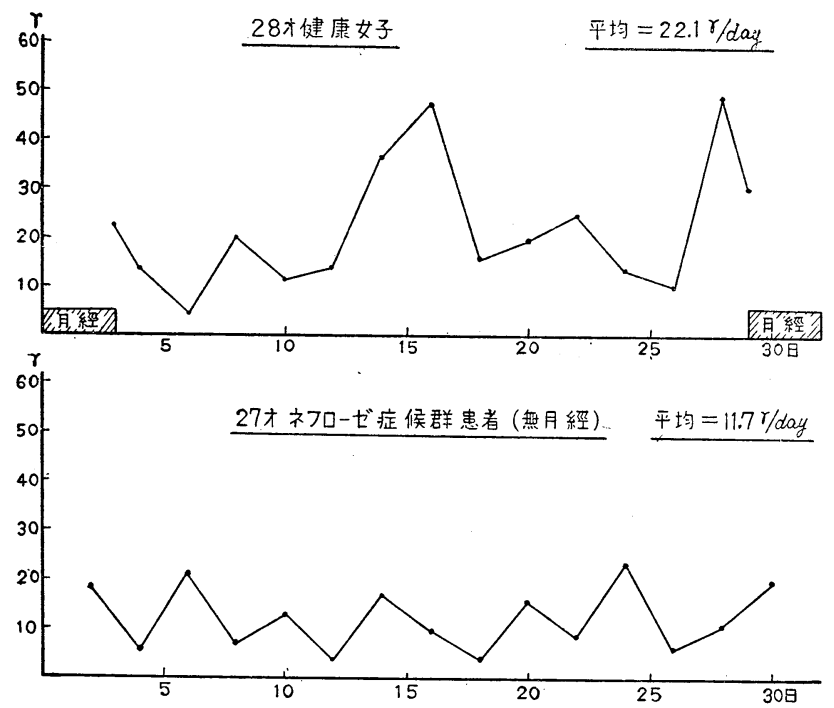

例では:排卵期に $41.3 \gamma$ 月経前期に 31.9r と最高ピークを示し，その平 均に゙ $19.5 \gamma /$ dayはであつた。

\section{第 2 項 ネフローゼ症}

\section{候群患者}

ネフローゼ症候群患者男子 7 例に

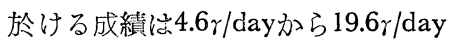
にて平均10.8 r/dayであつたが，浮腫， 尿量との間に心一定の関係に見出せ なかつた，次にネフローゼ症候群患 者女子で未だ浮腫期の無月経のもの を選び，健康女子と同様に隔日 1 力 月間測定したととろ，2 例共明らか なピークが認められなかつた。 その 平均值に於いて心第 1 例は 14.3 / day 第 2 例住11.7;/dayにて健康女子と比

較して明らかなに低值を示した。第 1 例はエストラジンテポーの注射にて正常月経が到来した。

第 3 節 小

括

尿中 estrone, estradiol 分劃の測定によつて健康女子 2 例に排卵期及び月経前期に 2 つのピークを認めた。 ネフローゼ症候群患者女子 2 例について 1 カ月間に亘り観察したが，ピーク心認められずその平均值隹健康 女子と比較して明らかに低值を示した，健康男子とネフローゼ症候群患者男子との䦛に绾特別の恋心認めら れなかつた。

\section{第 5 章＼cjkstart種々ホルモン負荷に於けるネフローセ症 候群患者尿中17KS分劃の変動 第 1 節 序訾}

ネフローゼ庭例群㭧者のステロイドホルモン代謝が健康者と異なる專统第 3 章及び第 4 章で述べた如く明 らかで岁るが，更に副留皮質ホルモン，忙ホルモンを連続投与した場合に於ける尿中 $17 \mathrm{KS}$ 分劃の变動を観 
察した。最近ネフローゼ症候群患者の治療に ACTH, cortisone 療法に代つて, prednisone, prednisolone が盛んに応用せられる様になつたが，ての prednisone 療法にて有効である場合と，全く効なくかえつて尿

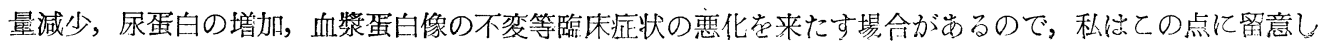
尿中 $17 \mathrm{KS}$ 分劃の相違を比較検討してみた。

\section{第 2 節 実 験 成 綪 \\ 第 1 項 ブレドニソン}

アメリカSchering 社製 prednisone (meticorten) をネフローセ症候群患者 5 例に使用し，穴の前後に於 ける尿中17K S 分劃の変動点観察したとてろ, 尿量の増加, 浮腫体重の減少, 尿蛋白の減少, 血清アルブミ

表 11 ネフローゼ症候群患者にプレドニゾン使用前後の17KS分劃

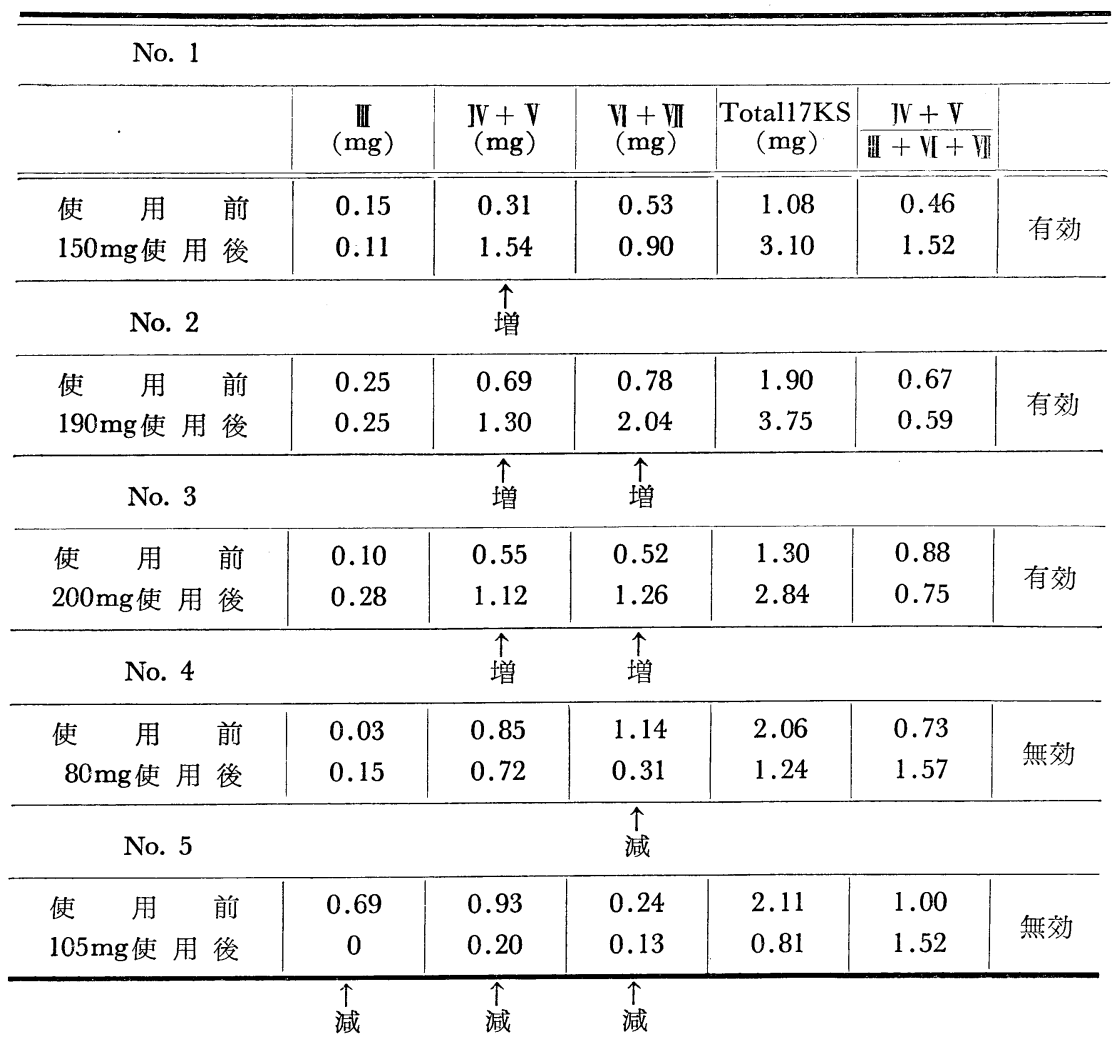

ンの增加等明らかに臨床的に有効と思われる第 1 例から第 3 例までに於ては，総 $17 \mathrm{KS}$ の增加をにじめ，IV

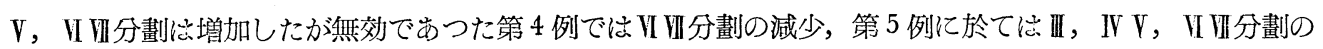
減少を来たした。即ち第 1 例は $15 \mathrm{mg} 10$ 日間計 $150 \mathrm{mg}$ 経口投与により, IV V 分劃注 0.31 加ら $1.54 \mathrm{mg}$, VIII分 劃は 0.53 から $0.90 \mathrm{mg}$ と增加し，第 2 例では 1 日 $20 \mathrm{mg}$ 漸減し13日間に $190 \mathrm{mg}$ を投与したが，VVV分劃は 0.69 加ら $1.30 \mathrm{mg}, V I V I$ 分劃は 0.79 から $2.04 \mathrm{mg}$ と堌加し，第 3 例では 1 日 $20 \mathrm{mg} 10$ 日間，計 $200 \mathrm{mg}$ 使用により，

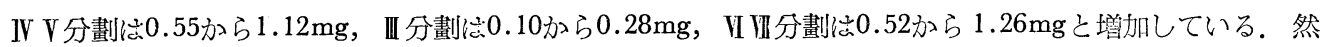

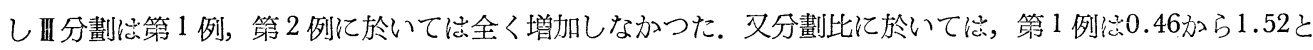
VVV分劃の增加が著明であつた. prednisone の無効であつた第 4 例に 1 日 $20 \mathrm{mg}$ 漸減して $80 \mathrm{mg}$ 投与したと てろ, 浮腫堌加, 発熱, 不整脈等の副作用が現われ中止した例で， 2 年前に心筇梗塞を起しているためとま， 
思オれるが，VIV分劃は $1.14 か ら 0.31 \mathrm{mg}$ と著明に減少した。第 5 例は13才男子のネフローゼ症候群患者で，

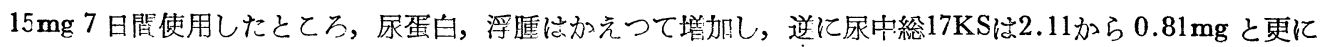

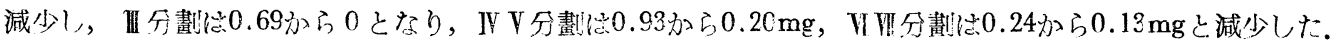

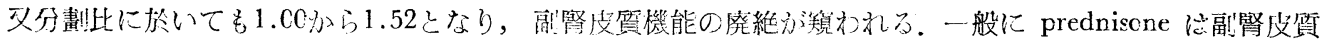

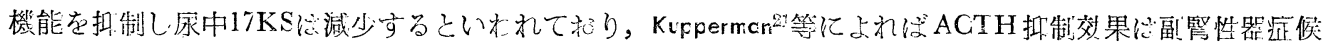

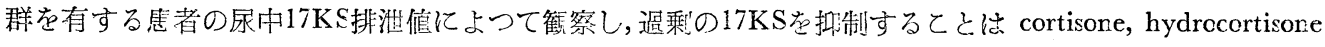
よりも prednisone, prednisolone の方か強力であると云こている. 然し glucccorticoid の荖倨に減少して

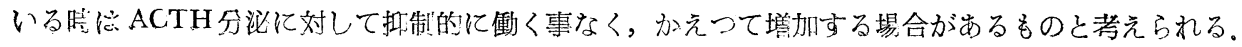

\section{第 2 項 テストステロン}

17才男子のネフローゼ症候群患者に testosterone propinate としてエナルモン1日10mgを隔日に筋注し， 6

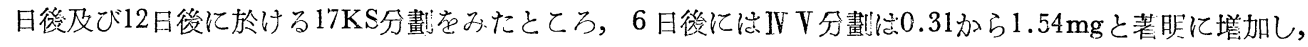

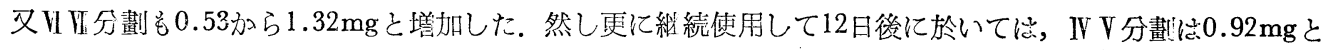

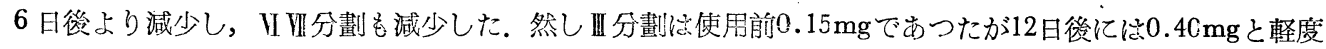

図 4 ネフローゼ症㞔群患者に TESTOSTERONE・ PROPIONATE 使用例
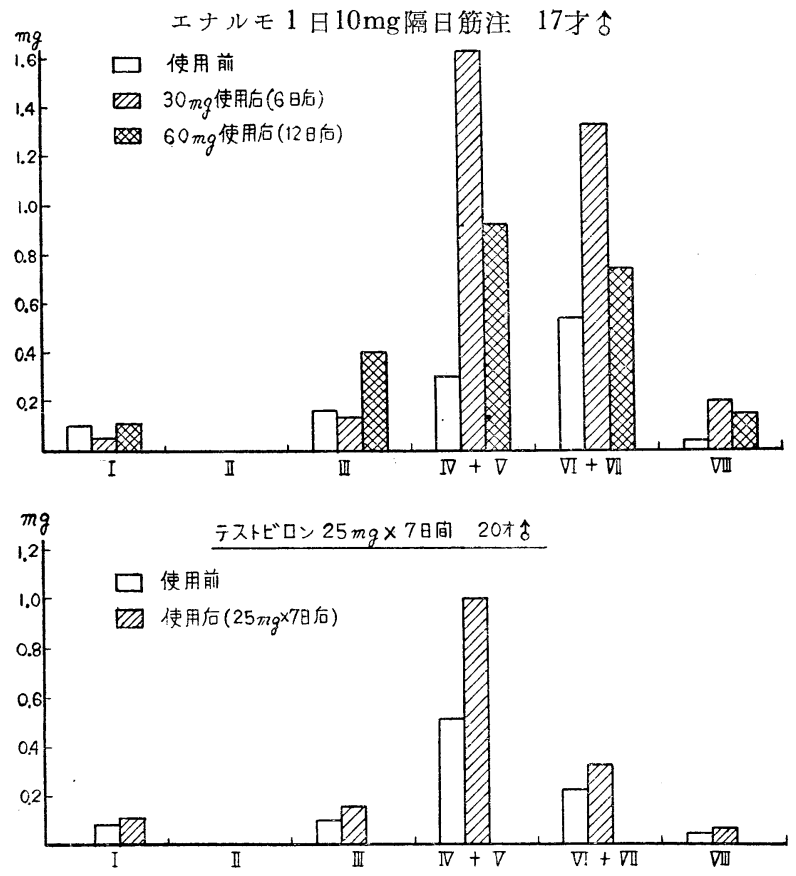

堌加した。IV V 分劃が 6 日後よ り12日後に於いて減少するのは， testosterone を長期に亘つて 使用す ると下垂体の gonadotropin, ACTH 分泌対して抑制的に働く為と思わ れる. Falcon ${ }^{14)}$ testosterone 注射 を行うとアドレナリンデスト時の好 酸球減少虻正常以下となるから， testosterone は下垂体加らの ACTH 分泌を抑制すると云つているが，私 の成續に於いても同椂の傾向がみら れる. 次に20才男子のネフローゼ症 候群患者に testovilon $25 \mathrm{mg}$ を連日 投与し 7 日間使用後では，IV V 分劃 は0.51 mg 加ら $1.04 \mathrm{mg}$ と增加を示し たが，他の分劃结殆んど変化なく， IV V と II VI VII 分劃の比借 0.96 か ら 1.66 となり，臨床症状全全く改善が みられなかつた。

\section{第 3 項 Methylandrostanediol}

(M.A.S.)

21 才男子のネフローゼ症候群患者に M.A.S. 1 日 $5 \mathrm{mg}$ 連続 1 週間使用したとてろ，IV V 分劃は使用前と

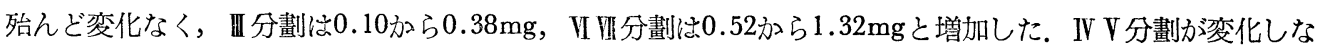

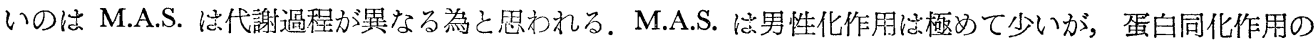
強いものとして利用されて打り，皆川吕等绾小児ネフローゼ患者に応用し，蛋白脱出に対抗して体蛋白の同

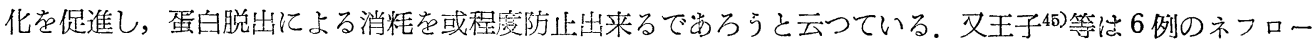
ゼ症候群患者に使用して尿量の堌加及び血清コレステリンの低下が認められたといつている．然し本症例に

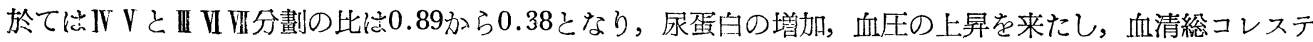


リンも $448.5 \mathrm{mg} / \mathrm{d} 1$ から $552 \mathrm{mg} / \mathrm{dl}$ と増加し，臨床的に増悪の傾向がみられたので投与を中止した。

第 4 項 エストラジオールについて

21才女子のネフローゼ症候群患者に estradin-depo $10 \mathrm{mg}$ を隔日 3 四筋注後に扔ける17KS分劃の変動は総

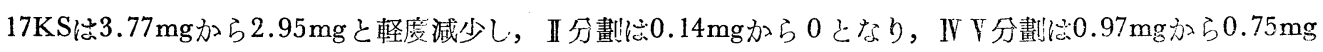
VIII分劃は $1.75 \mathrm{mg}$ 加ら $1.25 \mathrm{mg}$ と減少した. IV V 分劃と III VIVI分劃の比でば 0.41 から 0.39 と大差はない.

图 5 ネフローゼ症候群患者にMETHYLANDROS

TANEDIOL使用例

1 日 $5 \mathrm{mg} \times 7$ 日間筋注 21 才令
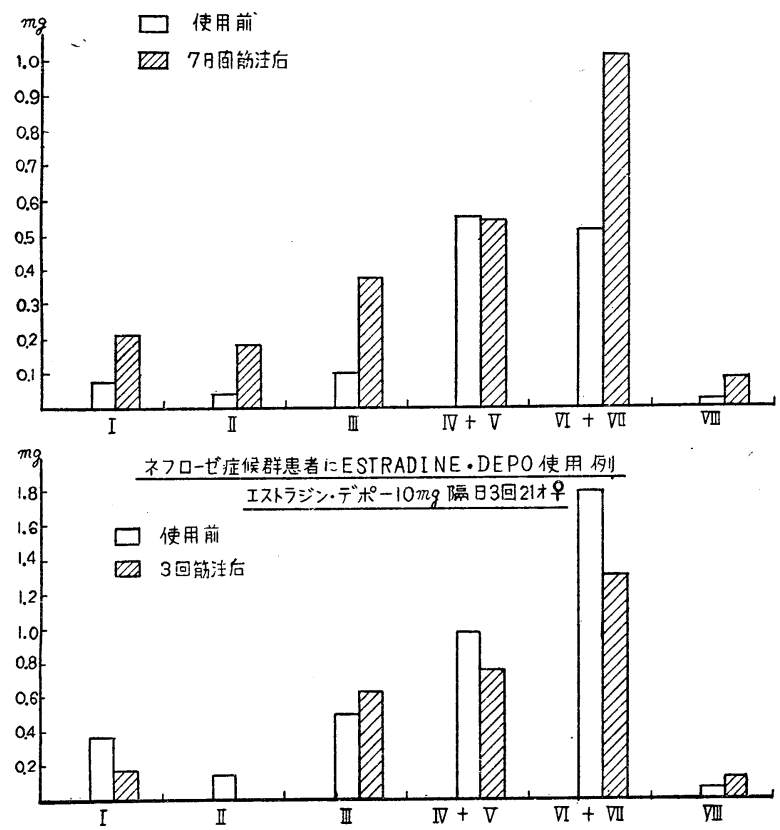

第3 節 小

括

ネフローゼ症候群患者 5 例に prednisone を使用したが明ら加に 臨床的有效であつた 3 例では廿四分 劃々增加を示儿, 又1V V 分劃皇增加 した. 然し無効であつた 2 例では， III, IV V, VI VI分劃は減少を示し， IV V と III VIV分劃との比は著明に增 加して glucocorticoid の分泌抑制が 認められた。 testosterone 投与では 2 例共 IV Y 分劃络増加したが，長期

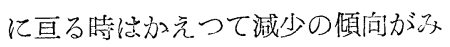
られた. M.A.S. では IV V は不変で めつた. estradiol 投与で虻，II，IN V VI IIf分劃织軽廈隇少した.

\section{第6章 総活ひび考按}

算疾患と副腎との関係について, 1937年 Selye $\mathrm{e}^{33}$ 结いわ的沉適応疾 患 (disease of adaptation) として

高血圧病，菱縮腎，腎炎，ネフローゼ症候群，ロイマチス椂疾患等を挙げている。 之によれ代高血圧病，萎

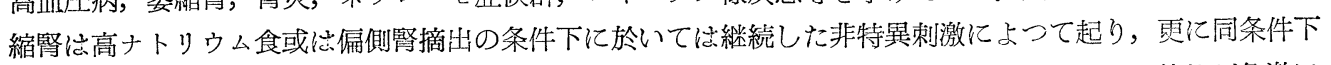

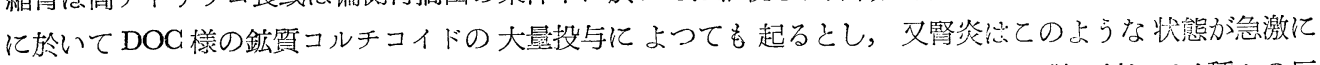
起つた場合, 即ち急性コルチコイド中毒によつて起ると報告した。しかしてのような説に対して住種々の反

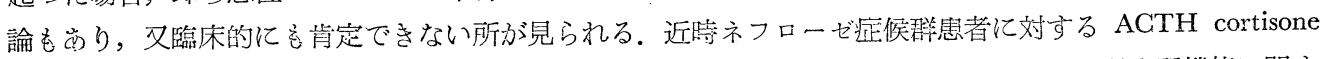

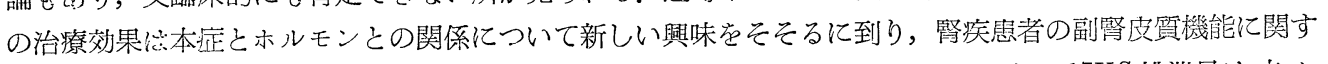

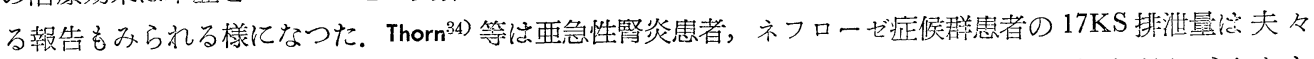
6.2mg庑び3.9 7.9mgでその減少を認め，ACTH 療法によりネフローゼ症候群患者の利尿が認められたと

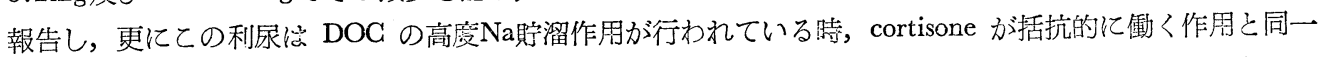

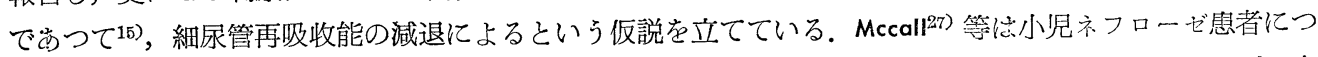

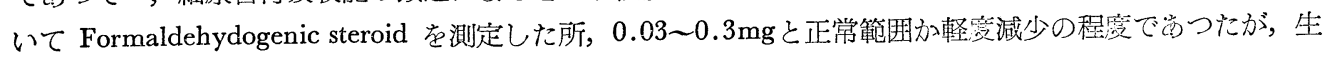

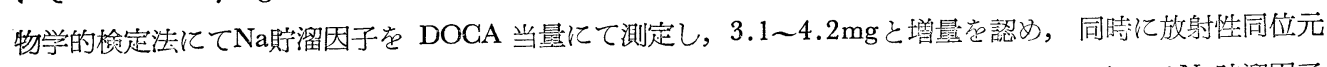

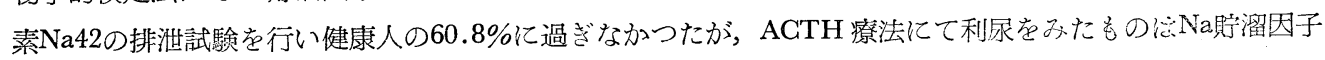

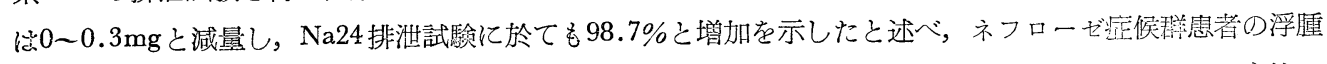

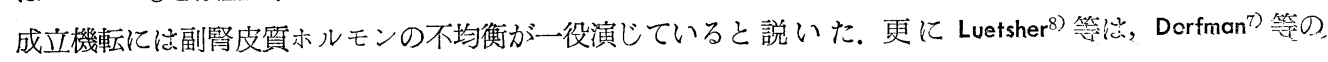


DOC の生物学的检定法を店用して，ネフローゼ患者の尿扯出物中に Na 貯溜因子が多量に含まれているて

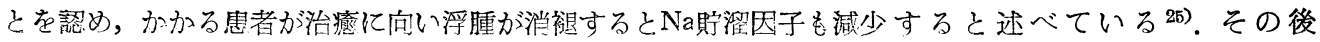

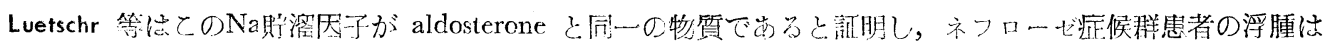

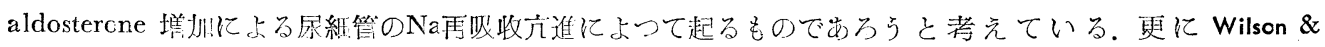

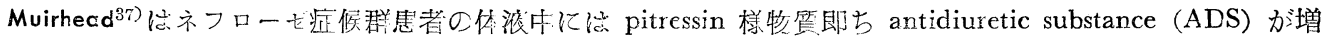
加している裹を認め，之が尿細管に作用し，水の再吸收を充進せしも，浮堙成立の一つの有力な原丙である と述べている.

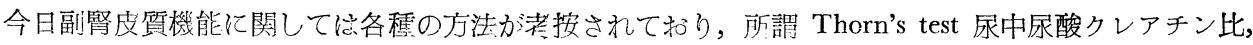

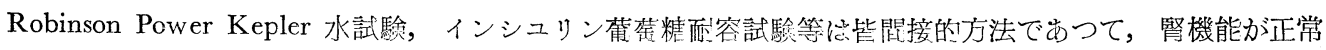
である事が条件となつているものが多い，従つて婜疾患の埸合气の副腎皮質機能を检索するに织ホルモン自 体或究その代誯物であるステロイドの測定によらねばならないと考えられる。然しコルチコイドば非特異的

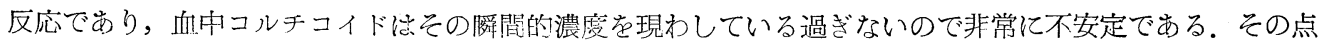
尿中の代謝産物统此較的安定していると思れれ，特に $17 \mathrm{KS}$ 绾浿定法も管便，且二精密化されて扔り，之を クロマトグラフィーによつて分離定量するてとは臨床的意義が大であると考えられる。

ステロイドホルモンが朋臟に於いて不活性化されるととを始めて記載したのは zondek (1934) であり， 彼は最初エストロゲン，ついでプロゲステロンについて証明した。 エストロゲンの不活性化は酵素的に行わ れるものであつて，ニコチンアるド及び DPN を加える事により不活性化作先に促進されるといねれ299，乙 の不活化には Vitamin B complex 特にB B biotin, Vitamin A は関係のないととが明がてれている. 又コルチコステロイドも組織と执いて作用する 他，主として拆に於いて不活性化され尿中に大部分にグルクロン酸と結合した形で排泄される。臨床実験で は Cantarow5)等が $200 \mathrm{mg}$ の testosterone を 1 回注射して，尿中に排出される17KSを回收し，慢性肝臟㷝㭧

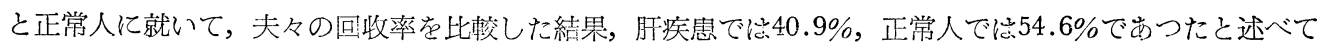
いる。私の実駼に於いてネフローゼ症候群患者の testosterone 代謝率は非常に悪く健康者の約将に過ぎなか

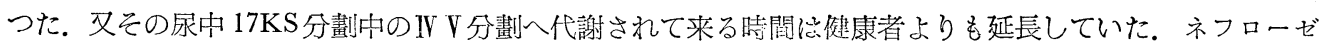
症候患者の代謝率が覀いのほ腎に於ける $17 \mathrm{KS}$ の排泄障碍も勿論考えなければならないが，肝に於ける䣼素 系の反応が健康者と異なるための代謝障碍であろうと考光られる。ずで腎疾患者に於けるステロイドホル モンの排泄減少织排泄障碍の為ではないがいう疑問が生じて来るが，之は元々微量の排泄であり，腎機能 障碍のある患者に於てもACTHの投与によりVI分分劃呮堌加を示し，ネフローゼ症候群患者の estrone ・ estradiol 分劃の測定でに健康女子の様に月経前期及び排卵期に相当する時期に増加する2つのピークを認め

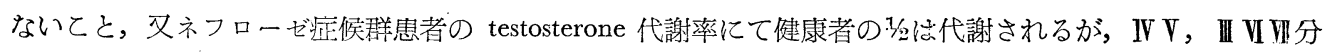

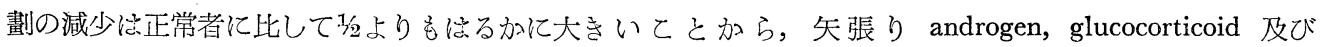
estrogen の分必低下並びそ代謝障碍が岕るものと考えて差し支えなからう。

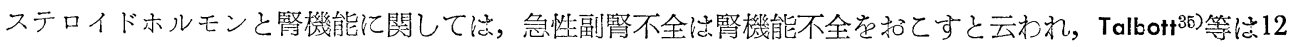
名のアジソン氏症患者に於いて Inulin clearance による糸球体滤過值（GFR）が減少して抢り，DOC或住

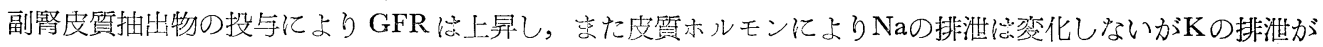

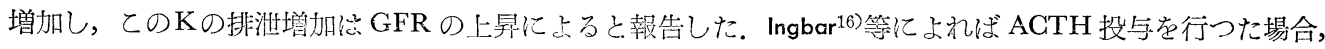

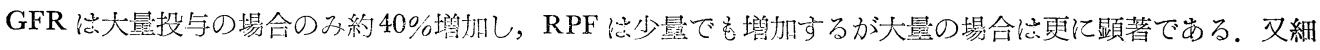
尿管排泄極量 $(\mathrm{TmPAH})$ に经変化を認めず，クレアチン，尿酸及燐酸のクリアランス試験に於いては少量 で影響少く，大量投与した崚のみ増加すると，更に cortisone の投与を行つた場合はACTHと大体同様で

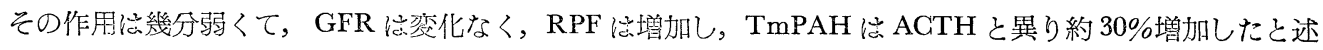

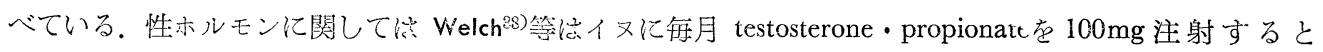

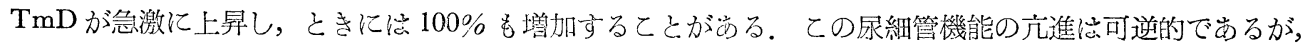

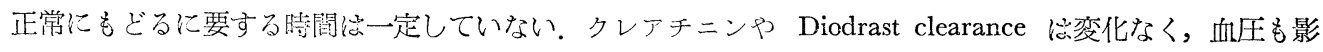


響をうけないと述べている. 人間で海毎日90〜300 mgの testosterone を与えて 8〜29日つづけても GFR, RPF，TmPAH，TmG などにとくべつの变化はない201. 又 Serkurt ${ }^{31}$ 等统 $\alpha$-estradiol をイ又或は正常婦人 に与えたときの腎機能をみているが，特別の变化点なく，去勢学行つても GFR，RPF，TmPAH，TmGい ずれも変化がないといつて扔り，览ホルモンのもつている水と Naの貯溜作用出副賢皮質のコルチコイドの

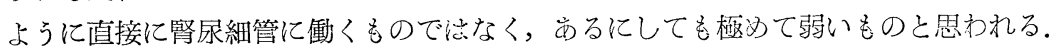

ネフローゼ症候群の症因論に関して心，末だ不明の点が多い溙で市るが，人の溶連菌感染後の急性腎炎が アレルギー反応によつて起るてと, 又人のネフロ一ゼ症候群か薬物毒物等の種々の抗原に対するアレルギー

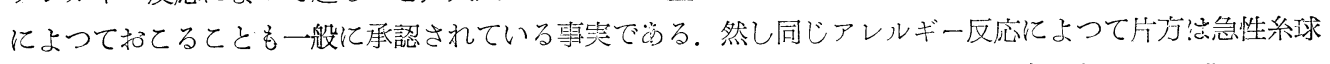

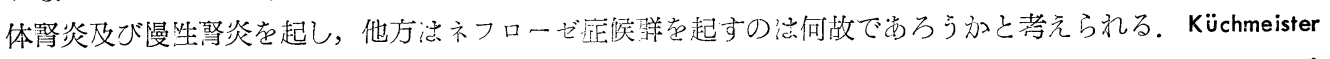

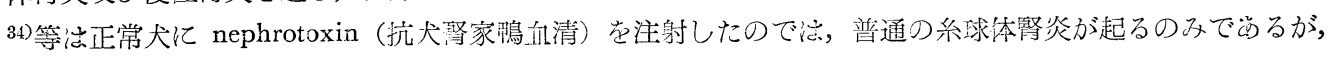
子邓 2 3 週間に亘つて plasmapheresis 繰返し hypoproteinaemia を起すと17KS 经減少の一途をたどる. この様な状態にして市る犬に nephrotoxin を注射するとネフローゼ泟候群の扔てるととを見出した。かく

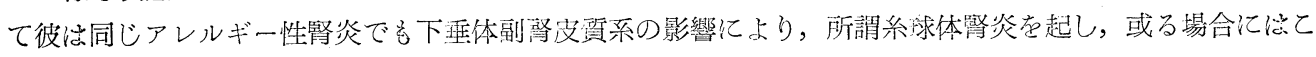

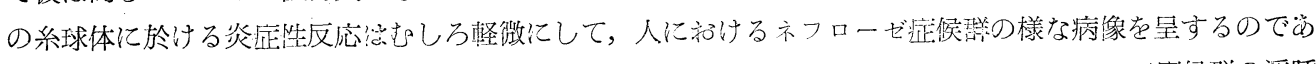

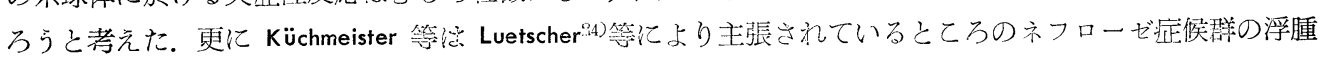
の成立には， aldosterone が画要な意義をるつているという説苍参落として，次の様な仮説をたてた，即ち

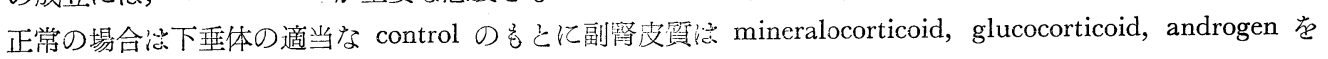

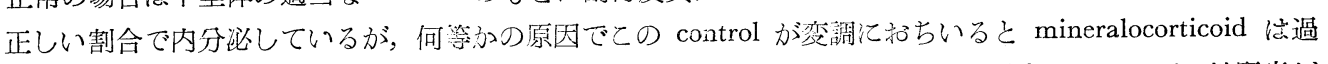

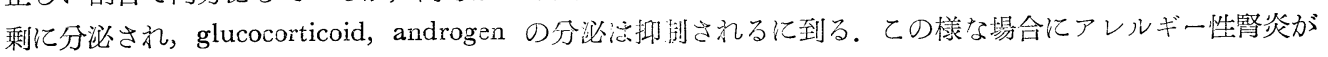
起るとネフローゼ症候样汇なる。而して AGTH， cortisone 療法化より緩快或终治瘾をもたらすのは mineralocorticoid, androg an, glucocorticoid の間つbalance が正常沉復するからでらると報告した.

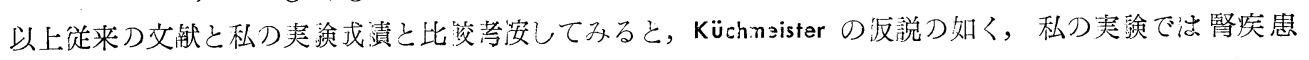

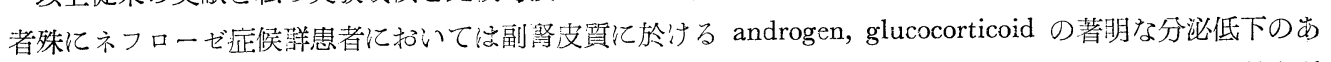

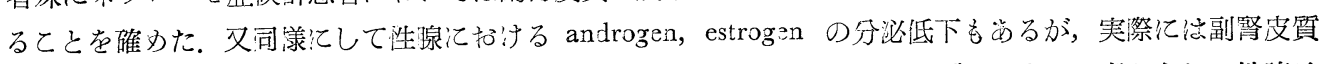

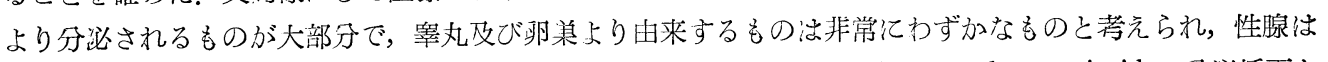

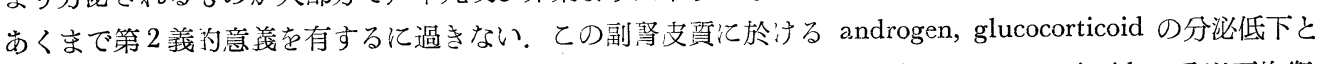

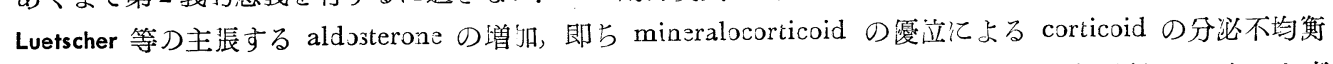

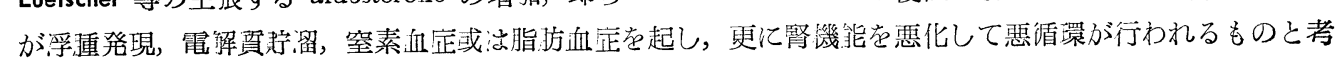
えられる。

\section{第 7 章 結 論}

(1) $17 \mathrm{KS}$ 分劃測定む microscale elution chromatography で夹施し，水王䎲よる加王法で一定加王犬態

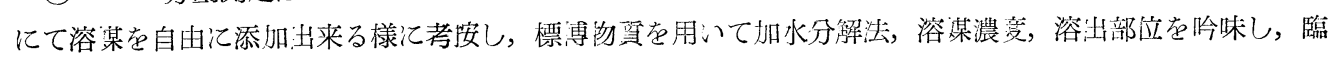
朱的価值の苛るとと学確わた。

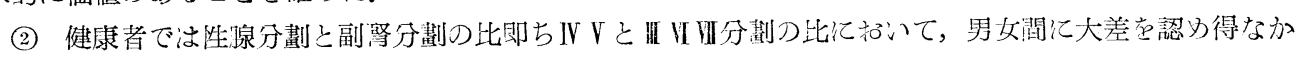
つた.

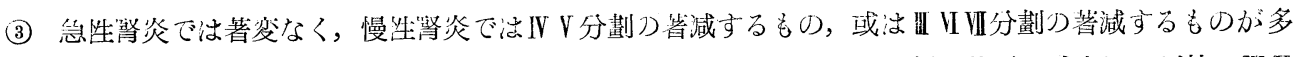

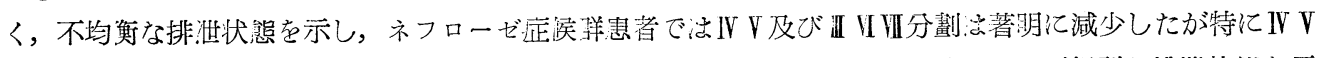

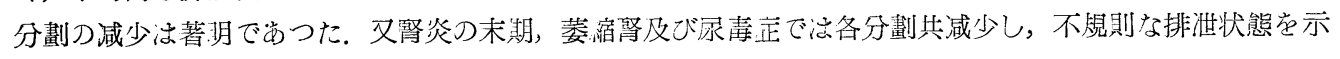
した.

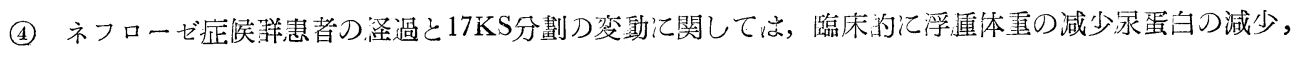
血漿蛋白像の改善伴つて, II, IV V, IIUI分劃仙增加した。

(5)ネフローゼ症候群患者に ACTH を投与してVIII分劃つ非泄增加をふたが，静注例つ場合は筋注例に 
比して遙が顕著であつた。

(6) ネフローゼ症候群患者に testosterone を负荷し，その代謝率を健康者と比較したが，約至程变しか代 謝されず，IV V と III UI 证分劃との balance 改善は健康者より遅延した.

(7) 尿中 estrone - estradiol 分劃の測定で心，健康女子 2 例に扔いて月経前期及び排贸期に 2 つのピーク

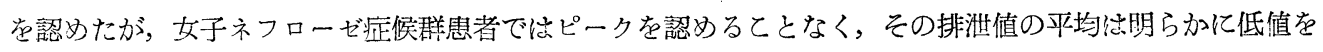
示した.

（8）ネフローゼ症候群患者に prednisone を使用した場合，臨床的に有効と認められた場合织，VIIII分劃

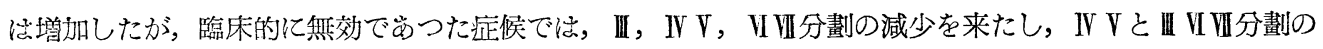
balance 恼不均衡となるのを認めた。

(9) testosserone をネフローゼ症候群患者に連続投与するとIV V 分劃彷增加するが，更に長期間に亘つて 投与する之下釷体の gonadotropin, ACTH を抑制して，IV V，UIII分劃共に減少を来たす。

以上の諸実驗結果汃ら，腎疾患者殊飞ネフローゼ症候群患者で恼，副腎皮質の androgen， glucocorticoid 系の機能低下，ならびに代謝障碍を認め，各種 corticoid の分泌不均衡に上る副腎皮質機能矢調症が脑るも の之考える. 又同溙に性腺に扔ける androgen， estrogen の分泌低下，ならびに代謝障碍も学るが，性腺住 節 2 次的意義を有するに過ぎない。しかして之等か腎疾患者の腎機能を更に增悪せしめ，又蛋白，水，電解 質, 肪代謝等に変化を及ばし，浮逼発現，電解質貯溜，窒素血症，或法脂肪血症等の症状を起す一要因とな るものと考える。

（稿を終るに臨み，恩師宇佐美教授並びに終始御指導御鞭撻を賜わり御校閲を頂いた山田教授に潹謝しま すと共に，御助言，御鞭样下さつた小林助教授，中日病院下村博士に感謝します).

\section{文献}

1) Burstein, S., Savard, K. \& Dorfman, R.I. : Endocrinol. 52 ; 448, 1953.

2) Biskind, M.S. \& \& Biskind, G.R. : Endocrinol. $31 ; 109,1942 . \quad$ 3) Conn, J.W. et al : J. Lab. \& Clin. Med. 43; 79, 1954. 4) Christian Hamburger : Ciba Foundation, Collquiaon Endocrinol. III ; 304, $1952 . \quad$ 5) Cantarow, N.H. et al : Endocrinol. 43 ; 97, 1948.6 6) Dingemanse, E.: Ciba Foundation, Colloquia on Endrcrinol II ; 251, 1952. 7) Dorfman, R.I. et al : Endocrinol. 41 ; 464, $1947 . \quad$ 8) Deming, Q.B. \& Luetscher, J.A. Jr. : Proc. Soc. Exp. Biol. \& Med. $73 ; 171,1951 . \quad$ 9) Dobriner, K., Lieberman, S. : Vitamins \& Hormones $X ; 251,1952$ 10) Edwards, W.H. : The determination of adrenocortical steroids and their metabolite.. London, Dennis Dobson P53. 11) Fornswarth, E.B.: J. Clin. Endocrinol. \& Metabol. 13 ; 1169, $1953 . \quad$ 12) Finkelstein, M. : Proc. Soc. Exp. Biol. \& Med. 69; 181, 1948. 13) Fukushima, K.,Dobriner, K. \& Gallagher, T.F. : J. Biol. Chem. 206 ; 845, $1954 . \quad$ 14) Falcon, W.W. et al : J. Clin. Endocrinol. $11 ; 173,1951 . \quad 15)$ Forsham, P.H., Flink, E., Emerson, K. Jr. : J. Clin. Invest. 28 ; 781, 1949. 16) Ingbar, S.H., Relman, A.S., Burrows, B.A. : J. Clin. Invest. 29 ; 824, 1950. 17) Joiler, J.W. : J. Clin. Endocrinol. 8 ; 564, 1918.118$)$ Küchmeister, H. : Pathologische Physiologie und Klinik der Nierensekretion Springer, Berlin, 1955, P221. 19) Korenchersky, V. \& Ross, M.A. : Brit. Med. J. $1 ; 645,1940 . \quad 20)$ Klopp, C., Young, N.F. \& Tayer, H.C. Jr. : J. Clin. Invest. 24 ; 189, 1945. 21) Kupperman, H.S. et al : J. Clin. Endocrinal. \& Metabol. 15 ; 911, 1955.22$)$ Kapass, A., Dobriner, K. \& Gallagher, T.F. : J. Clin. Invest. $34 ; 1559,1955.23$ 23) Lieberman, J. \& Dobriner, K. : J. Biol. Chem.172 ; 241, $1948 . \quad 24)$ Lnetscher, J.A. Jr. : J. Clin. Invest. $33 ; 276,1954.25)$ Luetscher, J.A. Jr. et al : J. Clin. Invest. $29 ; 1576,1950.26$ 26) Mandel, W. : J.A.M.A. 146 ; 546 1951. 27) Mccall, M.F. \& Singer, B.: J. Clin. End. \& Met. $13 ; 1,1953$. 28) Pond, M.H.: Lancet $2 ; 906,1951 . \quad 29)$ Rahoff, D.M., Cantarow, A. : Endocrinol. $43 ; 97,1948.20$ 30) Singlar, 
H.O. et al : J. Biol· Chem. $154 ; 79,1944$.

31) Selkurt, E.E., Talbot, L.J. \& Houck, C.R. : Am. J. Physiol. 140 ; 260, 1943. 32) Sarre, H. : Dt. Med. Mschr. 79 ; 1713, 1954.

33) Selye, H. :

Endocrinol. $21 ; 169,1937$.

34) Thorn, G.W., et al : Arch. Int. Med. 86 ; 319, 1950.

Talbos, J.H., et al : J. Glin. Invest. $21 ; 107,1942$.

36) Verdhuis, H. : J. Biol. Chem. 202 ; 107, 1953.

37) Wilson, H.E.C. \& Muirhead, A. : Acta Pediatr. 45 ; 77, 1956.

38) Welch, C.A, Rosenthal, Duncanad, M.T., Tayler, H.C. : Am. J. Physiol. 137 ; 388, 1942.

39) 三谷：日内分泌誌，30；482，1954.

大野：日内分泌誌，31；355，1955。

$41)$ 三宅 : 日内分泌誌，26；122，1950.

42) 下村 : 名古 屋医学, 発表予定.

43) 小田: 最新医学, $8 ; 923,1953$.

44）皆川等：ホルモンと瀶床，2；

1343, 1954

45) 王子等 : 日内分泌誌，31；143，1955. 